NBER WORKING PAPER SERIES

\title{
MULTILATERAL ECONOMIC COOPERATION AND THE INTERNATIONAL TRANSMISSION OF FISCAL POLICY
}

\author{
Giancarlo Corsetti \\ Gernot J. Müller \\ Working Paper 17708 \\ http://www.nber.org/papers/w17708
}

\author{
NATIONAL BUREAU OF ECONOMIC RESEARCH \\ 1050 Massachusetts Avenue \\ Cambridge, MA 02138 \\ December 2011
}

Paper prepared for the conference "Globalization in an Age of Crisis: Multilateral Economic Cooperation in the Twenty-First Century" organized by the NBER and the Bank of England. We thank Alan Taylor and our discussants Martin Feldstein and Domenico Siniscalco, as well as the participants at the conference, the pre-conference at the NBER, and seminars at the ECB and University of Paris 2 for very helpful comments. Patrick Hürtgen and Yu Jasmine Xiao provided excellent research assistance. The usual disclaimer applies. The views expressed herein are those of the authors and do not necessarily reflect the views of the National Bureau of Economic Research.

NBER working papers are circulated for discussion and comment purposes. They have not been peerreviewed or been subject to the review by the NBER Board of Directors that accompanies official NBER publications.

(C) 2011 by Giancarlo Corsetti and Gernot J. Müller. All rights reserved. Short sections of text, not to exceed two paragraphs, may be quoted without explicit permission provided that full credit, including (C) notice, is given to the source. 
Multilateral Economic Cooperation and the International Transmission of Fiscal Policy

Giancarlo Corsetti and Gernot J. Müller

NBER Working Paper No. 17708

December 2011

JEL No. E62,F42

\begin{abstract}
$\underline{\text { ABSTRACT }}$
During the global financial crisis 2007-2009 fiscal policy was widely used as a stabilization tool. Policymakers allowed a large build-up of public debt resulting from both automatic and discretionary expansionary measures. At the same time, calls for policy coordination stressed that international spillovers of fiscal policy might be sizeable. We reconsider the case for fiscal coordination by providing new evidence on the cross-border effects of discretionary fiscal measures. We rely on a vector autoregression model as well as on a quantitative business cycle model. We find that i) large spillover effects cannot be ruled out and, in contrast to conventional wisdom, ii) financial factors rather than trade flows lie at the heart of the international transmission mechanism. We discuss the implications of these results for policy coordination when markets price sovereign default risk, and put pressure on governments for implementing budget consolidation measures.
\end{abstract}

Giancarlo Corsetti

Faculty of Economics

Cambridge University

Sidgwick Avenue

CB3 9DD Cambridge, Cambs

United Kingdom

gc422@cam.ac.uk

Gernot J. Müller

University of Bonn

Kaiserstraße 1, 53113

Bonn, Germany

gernot.mueller@uni-bonn.de 


\section{Introduction}

In response to the global financial crisis, fiscal policy has been intensively used as a stabilization tool throughout the globe. In spite of academic contributions raising issues regarding the effectiveness of fiscal policy (see, for instance, Cogan et al. (2010) or Uhlig (2010)), there seems to be little doubt among policymakers that multipliers are quite sizeable. Even stronger appears to be the belief, shared in policy circles, that fiscal policy measures in a country are likely to have sizeable international spillover effects. At least, such a notion seems to have motivated calls for joint fiscal efforts in the context of the global financial crisis, at first to provide global fiscal stimulus to a failing global demand, then to stress the need for a moderation and delay of debt and deficit consolidation measures, especially among large countries with spare fiscal capacity. ${ }^{1}$

Yet, to date, the evidence on the size of international spillovers arising from fiscal measures taken at the national level is in short supply. ${ }^{2}$ Moreover, quantitative exercises based on standard models typically predict that cross-border effects are quite contained (see Cwik and Wieland 2010 and Corsetti et al. 2010c). Against this background, the present paper pursues two objectives. In the first part of the paper, after briefly reviewing the fiscal response to the crisis, we reconsider cross-border spillovers of fiscal policy within a vector autoregression (VAR) framework, as well as within a standard business cycle model. In the second part, we discuss the implications for policy cooperation in an international context characterized by high public debt and vulnerability to fiscal crises.

Our empirical analysis focuses on the US as the base country by virtue of their size and role in the world economy, as well as for reasons of data availability. Building on time-series studies on the effects of government spending shocks, we analyze the transmission of fiscal policy innovations originating in the US on economic activity abroad. We estimate a VAR model on quarterly time-series data for the period 1980-2007. In light of the current debate on the identification of exogenous shocks to government spending in time-series models, we actually adopt two different identification schemes. The first identification scheme, following Blanchard and Perotti (2002), posits that government spending is predetermined relative to the other variables in the VAR. The second scheme, which follows Ramey (2011), identifies spending shocks by using forecast errors computed on the basis of the Survey of Professional Forecasters.

Our main results - robust across identification schemes - are as follows. Focusing on the euro area

\footnotetext{
1“'Our highest priority in Toronto must be to safeguard and strengthen the recovery... We worked exceptionally hard to restore growth; we cannot let it falter or lose strength now. This means that we should reaffirm our unity of purpose to provide the policy support necessary to keep economic growth strong." (US President Obama in a letter to the G20 meeting in June 2010). On the occasion the EU called for unity in retrenchment: "Even though the timing, sequencing and scope of exit measures have to be tailored to conditions prevailing in the individual G20 members, coordination between governments can help to take into account possible spill-over effects." (EU letter to G20)

${ }^{2}$ In an early contribution, Canzoneri et al. (2003) study the effects of US fiscal expansions on selected European countries. Beetsma et al. (2006) provide estimates for spill-over effects within Europe.
} 
(EA) and the UK as trading partners, our estimates suggest that an increase in US government spending by one percent of US GDP raises output by about 0.5 percent in the EA and 1 percent in the UK. These peak effects occur after about 2 years. In addition, we find that the dollar depreciates strongly in real terms against the currencies of both trading partners. Importantly, we also find the response of trade flows quite moderate, such that it fails to provide a rationale for sizeable output spillovers.

We therefore attempt to interpret these findings through the lens of a standard two-country business cycle model. Each country is assumed to specialize in the production of a specific set of intermediate goods which are consumed by private households and the government. In the model, while households act so as to maximize their welfare subject to constraints on prices and wage setting, monetary and fiscal policy are characterized by feedback rules. The specification of the monetary rule is a standard Taylor-type rule. As regards fiscal policy, motivated by the results from our VAR and previous work of ours (see Corsetti et al. (2011c)), we model a budget rule allowing for a systematic response of taxes and government spending to public debt. As a result, an exogenous, debt-financed increase in government spending implies a spending reversal after some time, that is, a decline of government spending below trend after the initial increase.

Using model simulations, we find that the model does not have an easy time to generate spillover effects of government spending shocks on foreign output which come close to the magnitudes implied by the point estimates obtained from the VAR. Qualitatively, the model predictions align well with the evidence only when we allow for spending reversals (suggested by the empirical evidence). Only in this case, we find a depreciation of the real exchange rate and a gradual build-up of foreign activity, in line with our VAR results.

We argue that this result illustrates most clearly the importance of accounting for a "financial channel" in the international transmission mechanism. Specifically, what happens in the model economy is that, given the monetary and fiscal feedback rules in place, an increase in domestic government spending triggers expectations of a future spending reversal and reduced real interest rates in the medium run. Expectations of lower future real rates reduce, all else equal, current long term real rates in both countries. It is through this financial channel that expectations of future fiscal and monetary policies impact on current private expenditure both in the domestic economy and - transmitted via international asset prices - in the foreign economy.

In the second part we discuss the implications of our findings - that is, the presence of large crossborder spillovers as well as the importance of the financial channel - for policy cooperation in an international context. Specifically, in the light of the deterioration of the fiscal outlook in developed countries documented in section 2 , we discuss the challenges to stabilization policy in an environment of high public debt and vulnerability to fiscal crises, as reflected by large and volatile risk premia charged on sovereign bonds. To address this issue properly, the conventional model underlying calls 
for cooperation needs to be amended, so as to account for the effect of sovereign risk on private borrowing costs. In related work, we have shown that this effect defines a distinct and powerful channel of transmission, the sovereign risk channel (see Corsetti et al. 2011a). This effect raises the vulnerability of the global economy to a downturn driven by self-fulfilling expectations in countries with a deteriorated fiscal outlook, and without room for further monetary stimulus. While a fullfledge international model accounting for the sovereign risk channel is not yet available, we argue that the tangible threat to global recovery created by sovereign risk arguably lends support to coordinated fiscal initiatives. Such initiatives would need to combine gradualism in budget correction by countries with some fiscal space with decisive and credible debt consolidation measures in countries facing market pressures.

\section{The fiscal response to the crisis}

In this section we briefly review the adjustment of fiscal policies during and in the wake of the global financial crisis. While global in nature, the crisis impacted countries and/or regions differently, possibly also as a result of different policy responses. Figure 1 displays annual output growth for the world economy, for a sample of advanced economies and a sample of emerging and developing economies (IMF classification). ${ }^{3}$ The global financial crisis which, according to the common narrative, started in 2007 in the US sub-prime housing market, made itself felt in terms of economic activity in 2008: output growth declined sharply and turned negative for the world economy in 2009. In fact, output growth declined sharply in both country groups under consideration and by a similar amount in terms of percentage points. Yet as output growth was lower in the advanced countries group during the pre-crisis period, actual output declined substantially only in this group.

The US and the EA were among the regions hardest hit by the crisis; this has dramatic implications for policy-making. Figure 2 illustrates this point by displaying measures of unemployment and the short-term interest rates in both the EA and the US for the period 2005-2011. Although the rise of unemployment masks dramatic differences within the EA, the aggregate picture resembles the developments in the US rather closely (the increase is larger in the US, however). Monetary policy responded to the crisis by lowering interest rates, quickly running into the zero lower bound problem, and by adopting unconventional measures (on the latter, see for instance Meier 2009). Yet the effectiveness of these measures remains an issue of controversy to date (see, e.g., Del Negro et al. (2010) for a positive assessment) and the significant uncertainty about the way they transmit to the economy has probably constrained central banks in relying on such measures. Overall, the capacity of monetary policy to stabilize the economy in the aftermath of the global financial crisis has arguably

\footnotetext{
${ }^{3}$ According to the IMF classification, there are 34 countries within the advanced economies group and 150 countries within the emerging and developing countries group.
} 


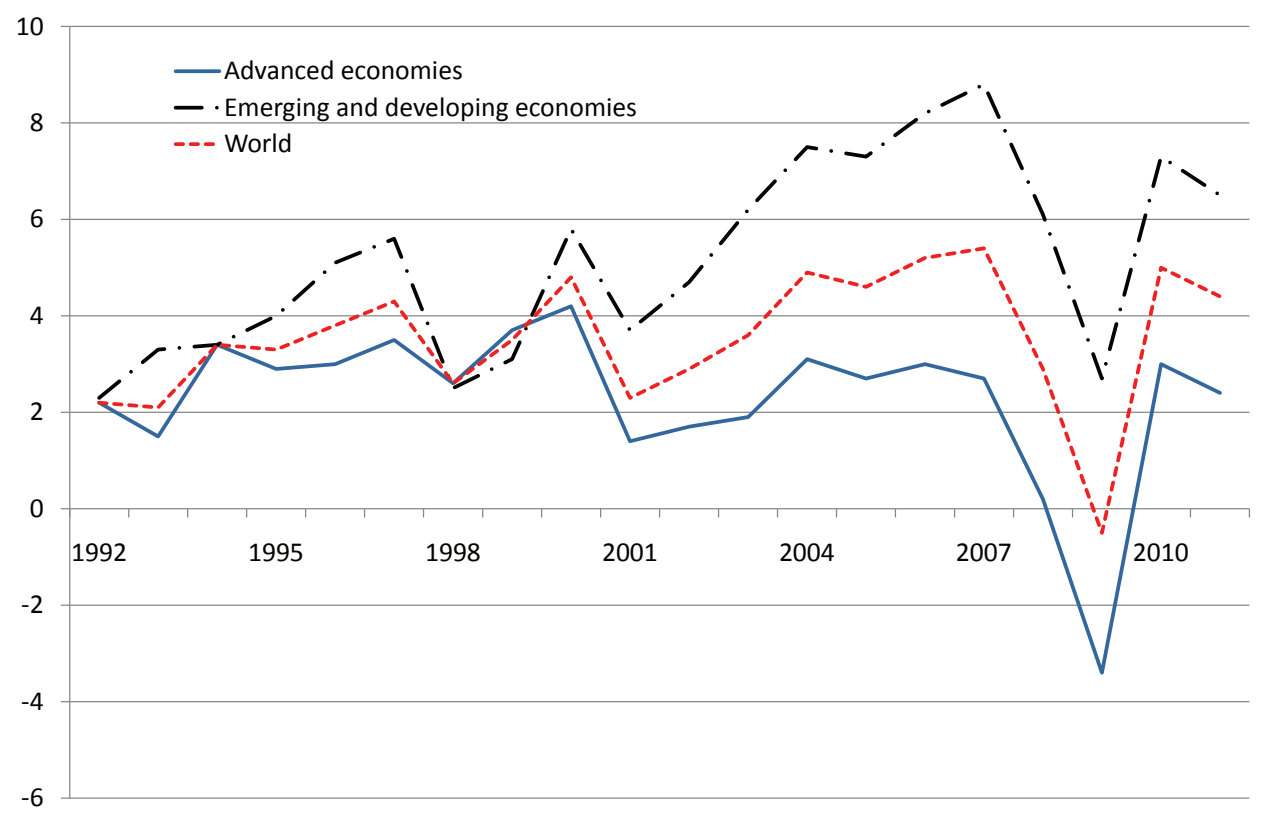

Figure 1: Annual GDP growth (in percentage points) 1992-2011 in world and regions. Source: IMF.

been limited.

With the decline in activity, budget deficits soared as a result of revenue losses, and increases of government spending with the objective of providing stimulus to the economy and support to the financial sector. In figure 3 we plot general government debt in 2010 as a percentage of GDP for a sample of OECD countries. The figure highlights the sharp increase during the period 2007-2010, reflecting the cumulative effect of government budget deficits in the years 2008, 2009, and 2010. While the recent rise in debt is dramatic, it is not unprecedented. Taking a historical perspective, Reinhart and Rogoff (2008) show that public finances frequently deteriorate on a similar scale in the wake of a financial crisis - with an average increase in the debt-to-GDP ratio of 80 percent in the three years following the crisis.

In order to take up the issue of coordinated policy actions, it is of particular interest to identify the discretionary component in the fiscal response to the crisis, a task which in turn requires an estimate of the automatic adjustment of the government budget. According to standard practice, we focus on the cyclically-adjusted government budget balances, defined as the government budget balance which would prevail if output were at its natural level. Based on OCED data, we compute a simple measure of the discretionary fiscal response to the crisis: the decrease in the cyclically adjusted primary government budget balance (CAPB) in the years 2008, 2009 and 2010 relative to the pre- 


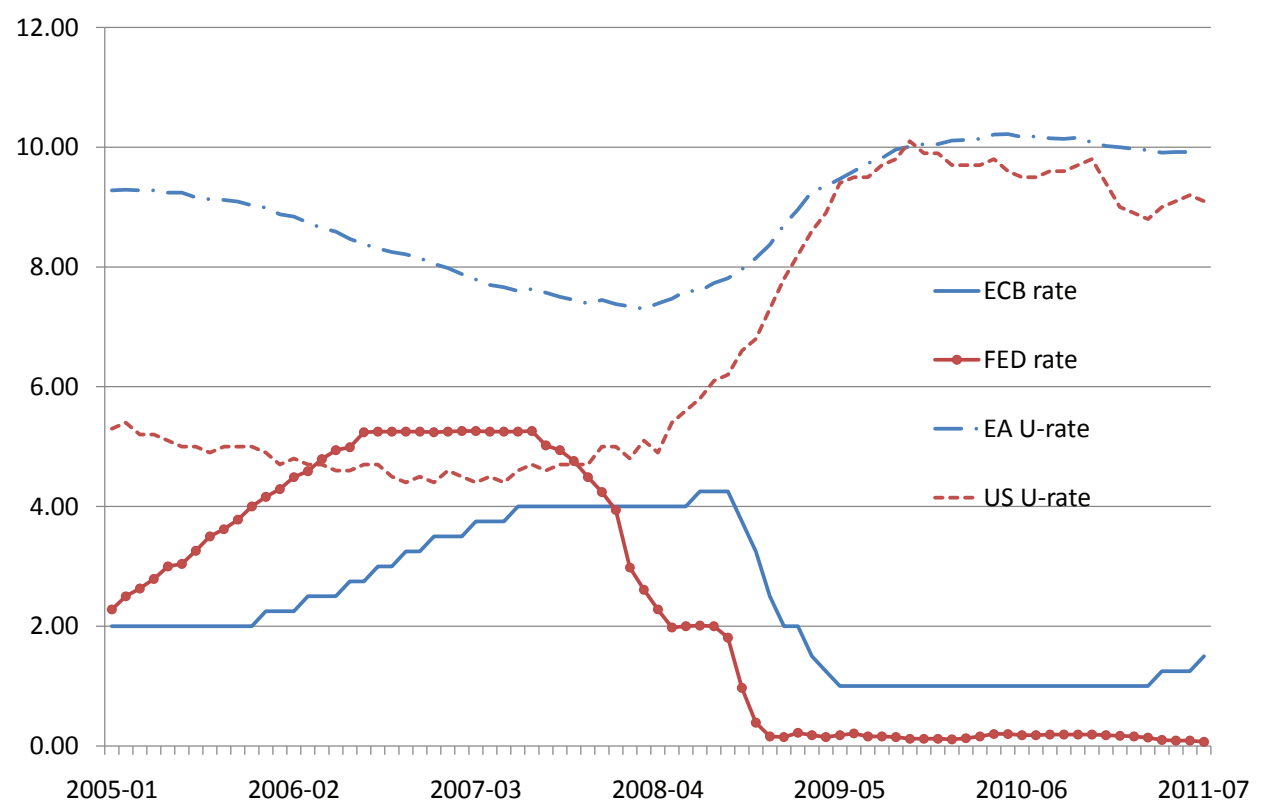

Figure 2: Unemployment and short-term interest rates 2005M1-2011M7 (in percentage points) in EA and US. Sources: Bundesbank, St. Louis Fed and ECB.

crisis level in 2007. ${ }^{4}$ In principle, the sum of these changes should account for deliberate policy measures taken on top of the automatic budget adjustment to the economic downturn. It thus captures discretionary stimulus measures such as temporary increases in government spending or tax cuts which have been traditionally considered instruments of stabilization policy. They were also used during the crisis with a view to support economic activity. The most widely discussed measures include the American Recovery and Reinvestment Act legislated in January 2009 and the European Economic Recovery Plan introduced in the EU in November 2008.

In addition to these "conventional" discretionary fiscal measures, several governments provided substantial support to the financial sector. Such measures include lending and recapitalization operations, as well as asset purchases at market prices. To the extent that these transactions do not necessarily involve capital losses, they raise gross debt, but not net debt. To get a sense of the magnitudes of these "unconventional" discretionary fiscal measures, we thus compute the difference between the

\footnotetext{
${ }^{4}$ See Girouard and André (2005). The data are constructed on the basis of a disaggregated approach, computing the response of different budget items to the cycle. The approach distinguishes four sources of tax revenues: personal income taxes, social security contributions, corporate income and indirect taxes; in addition the estimates take into account unemployment-related transfers. For all five categories, the output elasticity is decomposed into i) the tax-base elasticity of a particular revenue/expenditure type and ii) the output elasticity of the tax/expenditure base in question. These components are quantified on the basis of different estimation strategies and combined to compute the output semi-elasticity of the budget.
} 


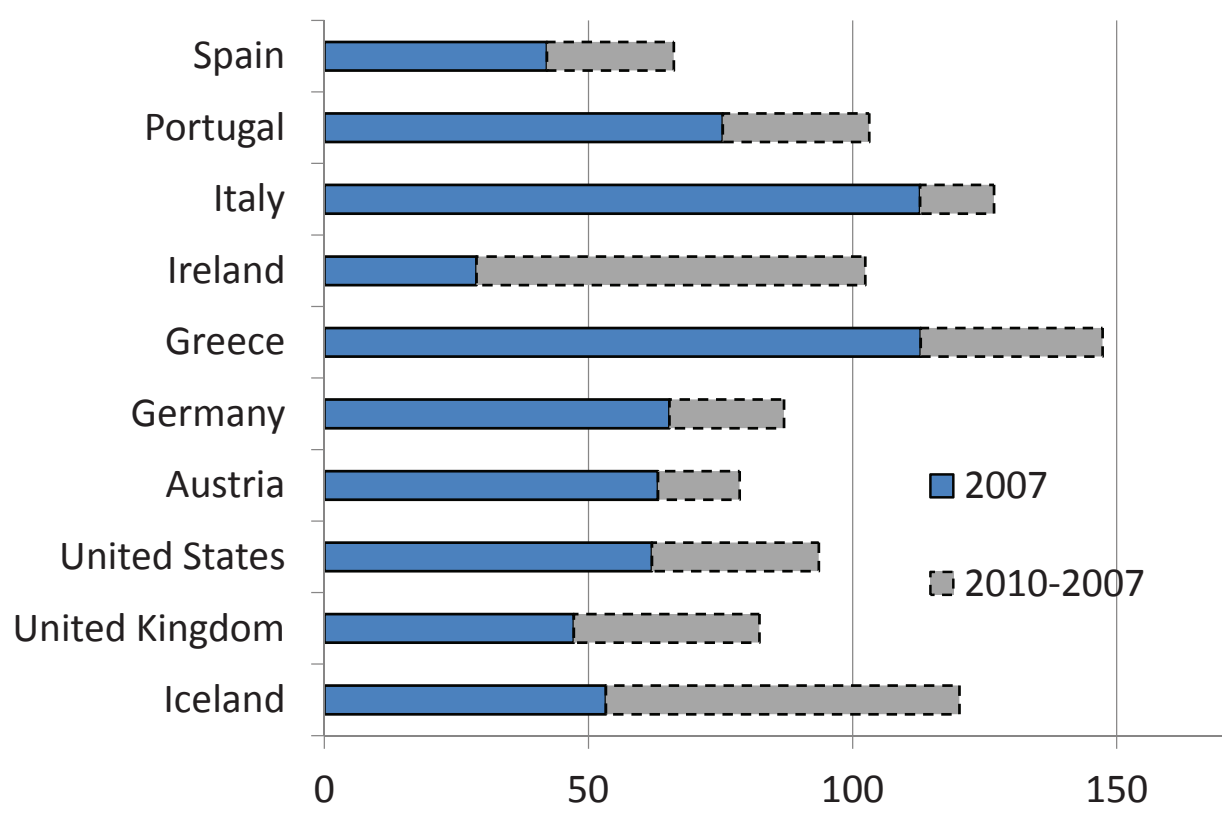

Figure 3: General government gross financial liabilities as of 2010 (percent of GDP). Source: OECD.

increase in gross and net debt. Figure 4 provides a graphical representation of the cumulative CAPB decrease and the difference in the increase between gross and net government debt for a sample of OECD countries. It also shows that remaining increase in gross debt, which is unaccounted for by our measures for discretionary fiscal policy. It provides a measure for the automatic deterioration of public finances during the crisis (which, in turn, captures the decline in revenues, lower output growth and possibly higher interest rates). According to this breakdown, there is substantial cross-country variation in the fiscal response to the crisis. ${ }^{5}$

The measure of the conventional discretionary fiscal response to the crisis introduced above is admittedly crude. In some dimensions, it is likely to overstate the role of discretion. For instance, the budget balances of numerous countries took a beating beyond what can be accounted for by the decline in economic activity, because of the extraordinary declines in tax revenues driven by falling asset prices and financial sector profits (see, e.g., Horton et al. 2009). In this respect, the OECD's measure of the cyclically adjusted primary balance is likely to pick up an exceptional decline in the government budget balance which is not entirely due to discretionary policy action. Nevertheless, our measure should provide some idea of the importance of various fiscal measures for the increase of

\footnotetext{
${ }^{5}$ Benetrix and Lane (2010) also document substantial heterogeneity in fiscal outcomes in a systematic cross-country analysis of the fiscal stance during the crisis. In particular, they find that differences cannot be fully explained by differences in the GDP performance.
} 


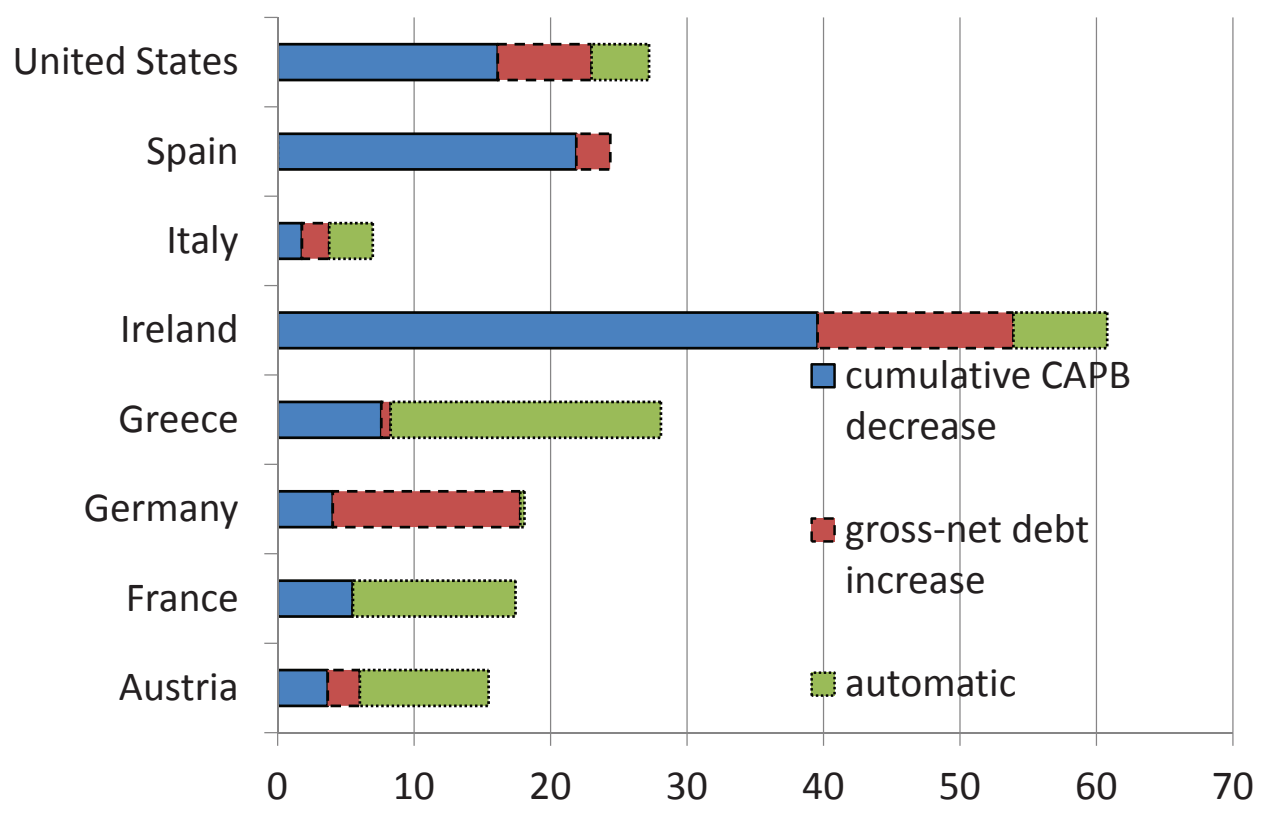

Figure 4: Increase of gross general government debt 2007-2010 (percent of GDP): cumulative decline of CPAB, gross-net debt increase, and remaining increase. Source: OECD and authors' calculations. Note: cumulative CAPB decline is the sum of change in cyclically adjusted primary balance (as reported by OECD) in each year 2008, 2009 and 2010 relative to pre-crisis level in 2007.)

government-debt levels.

Indeed, a similar picture emerges from IMF estimates of the size of narrowly defined discretionary stimulus measures, reproduced in the left panel of Table 1. These estimates are based on an in-depth analysis of national budget documents and medium-term fiscal plans in selected countries. Again, the concerted effort around the globe to provide support to economic activity through discretionary fiscal measures is apparent from the Table, despite sizeable differences across countries. The right panel of Table 1 reproduces estimates of the support to the financial sector. While sizeable, these measures have not necessarily been recorded in the budget.

In spite of the difficulties in estimating automatic and discretionary measures, there is a sense in which a sizeable fiscal response to the crisis has been deliberate in most advanced countries. Facing rapidly falling output, governments have been intentionally refraining from undertaking any action to compensate for the automatic increase in their budget deficit in response to the fall in economic activity and asset prices. On the contrary, they have resorted to discretionary expansionary measures, and provided generous (contingent) support to the financial sector. Public debt, risen markedly over the period 2007-2010, is likely to persist at the new high level for many years, as far as advanced 
Table 1: Discretionary fiscal measures

\begin{tabular}{lccccc}
\hline & \multicolumn{3}{c}{ Crisis-related stimulus } & & $\begin{array}{c}\text { Financial sector support } \\
\text { up to 2010 }\end{array}$ \\
\cline { 2 - 4 } China & 2009 & 2010 & 2011 & & $\ldots$ \\
\cline { 2 - 4 } Italy & 3.1 & 2.7 & $\ldots$ & & $\ldots$ \\
France & 0 & 0 & 0 & $\ldots .8$ \\
Germany & 1.2 & 1.1 & 0.6 & $\ldots .8$ \\
Russia & 1.7 & 2.2 & 1.7 & $\ldots$ \\
Saudi Arabia & 5.5 & 5.3 & 4.7 & 7.1 \\
Spain & 5.4 & 4.2 & 1.6 & 7.1 \\
UK & $\ldots$ & $\ldots$ & $\ldots$ & 5.2 \\
US & 1.6 & 0.0 & 0.0 & $\ldots$ \\
\hline
\end{tabular}

Numbers are percent of GDP. Discretionary fiscal tightening not shown. “..." indicates that there are no observations. Source: International Monetary Fund (2010) and International Monetary Fund (2011) .

economies are concerned (see Figure 5).

The large fiscal expansion in the first years of the crisis occurred among calls for coordinated stimulus, consistent with the notion of strong cross-border spillovers from fiscal policy. Whether or not global stimulus was truly cooperative, that is, to what extent national policy makers actually internalize international spillovers resulting from their measures, is difficult to say. Nonetheless, it would be a mistake not to recognize the coordinated convergence onto a policy model overruling prescriptions of budget austerity often followed in previous crisis episodes at the national or regional level. More or less explicitly, governments have recognized the mutual benefits from sustaining aggregate demand at the national and global levels, and also from engineering a massive transfer of risk from the private to the public sector balance sheet.

Traditional arguments feeding skepticism on coordinated actions fall into three categories, questioning feasibility, sustainability and size of spillovers in turn. First, coordination is not viable because decision and implementation lags cause coordinated measures to be taken at inappropriate times. Second, the international community does not have effective instruments to ensure that coordinated measures are diligently adopted by the national governments. Third, empirical and theoretical work cast doubts on the size of international spillovers. More specifically, once governments keep their house in order, that is, they implement optimal stabilization policy from an inward-looking perspective - the gains from further refinement of these policies (internalizing cross-border spillovers) are minuscule. The international community thus has much more to benefit from disciplined stabilization policy at the national level (see Corsetti et al. 2010a among others).

Of these three open issues regarding coordinated policy, the third one has perhaps dominated the 


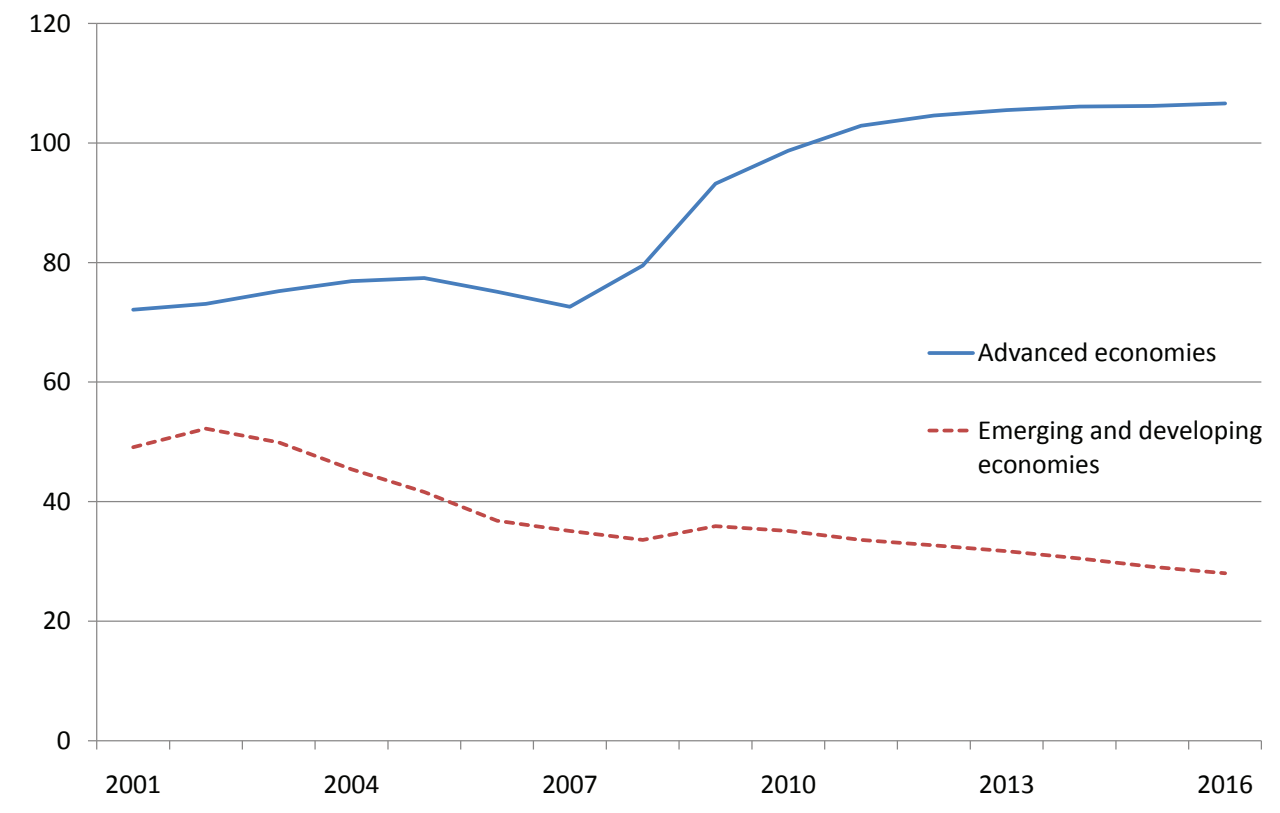

Figure 5: General government gross debt (percent of GDP) in advanced economies and emerging and developing economies, according to IMF classification. Source: IMF.

recent debate. It is also implicit in concerns expressed by observers raising doubts on the rationale of providing fiscal stimulus in the first place (see Barro 2009 and Cogan et al. 2010 among others), even at the national level. In what follows, we take up the same question but with a distinct focus on cross-border spillovers, partly because this is where the disagreement in both policy and academic circles is most apparent, and partly because the answer to this question appears to be a fundamental prerequisite for any further analysis of policy coordination.

\section{Cross-border effects of fiscal expansion}

We draw on two distinct approaches to formally assess the importance of cross-border effects of fiscal policy. In both instances we to explore the domestic and international repercussions of an exogenous change in government spending. This experiment is informative in identifying the specific transmission channels through which fiscal policy measures impact on the (global) economy. In the first part, we rely on an estimated vector autoregression (VAR) model to establish time-series evidence on the basis of minimum set of a priori assumptions. In the second part, we try to shed light on this evidence using a standard business cycle model. 


\subsection{Time-Series Evidence}

As a case study, our empirical analysis focuses on the international repercussions in both the euro area (EA) and the UK, of an exogenous change in government spending in the US. As explained below, focusing on the US as the base country allows us to compare results from conceptually distinct identification schemes (see also our discussion in Corsetti et al. (2011c)). In addition we shed light on spillovers from the largest economy in the world, onto economies which differ substantially in their relative size. In our study, we are specifically interested in studying the cross-border effects of a US spending expansion on economic activity in the EA and the UK, as well as on the US bilateral trade with these economies.

\subsubsection{Identification and specification}

During the last decade, a large number of studies have attempted to characterize the fiscal transmission mechanism using VAR models, mainly in a closed economy context. Following Blanchard and Perotti (2002), many of these studies identify fiscal shocks (as opposed to systematic policy responses to economic conditions) assuming that government spending is predetermined relative to the other macro variables included in the VAR. ${ }^{6}$ This assumption appears plausible to the extent that government spending does not include transfers, which vary automatically with the cycle, and that decision lags prevent policy makers from responding instantaneously to the state of the economy.

Yet this approach to the identification of government spending innovations is subject to the criticism that changes in government spending, while unrelated to the state of the economy, may be partly anticipated by economic agents - a point which has been forcefully made by Ramey (2011), among others. In an alternative approach developed by this author, government spending shocks are identified with forecast errors made by professional forecasters. The series of these errors is then included as an additional variable in the VAR model and is ordered first. ${ }^{7}$ Its dynamic effects are then computed on the basis of impulse response functions implied by a recursively estimated VAR model.

In the following we report results obtained under both identification schemes. We estimate variants of a VAR model on quarterly time series for the period 1980:1-2007:4, that is, we do not consider the crisis period. Our VAR model includes four US time series: government spending and output (in logs and real terms), a measure of long-term real interest rates (quarterly percentage points) and public debt (scaled by quarterly GDP). To analyze the effects of US spending shocks, for either the EA or the UK, we include the bilateral real exchange rate and, in order to economize on the degrees of freedom, we rotate, as the last variable, bilateral exports, bilateral imports, bilateral trade balance,

\footnotetext{
${ }^{6}$ Under this assumption, innovations to government spending represent exogenous innovations in a recursively estimated VAR model, with government spending ordered first.

${ }^{7}$ Specifically, Ramey computes the forecast error of quarterly government spending growth on the basis of the survey of professional forecasters maintained at the Philadelphia Fed.
} 
and foreign output, in turn. The VAR model also includes a constant and a linear time trend.

\subsubsection{The transmission of spending shocks in the US economy}

The transmission of US spending shocks in the US economy are displayed in Figure 6: the left column ("VAR innovation") refers to the Blanchard-Perotti identification scheme, the right column ("Forecast error") to the alternative identification scheme due to Ramey (2011). ${ }^{8}$ In either column, the size of the shock is normalized so that government spending increases by one percent of GDP on impact.

In these and all the graphs to follow, the solid lines display point estimates, while the shaded areas indicate 90 percent confidence bounds obtained by bootstrap sampling. The horizontal axis measures quarters. Output and government spending are measured in output units, so that the response of output provides a direct measure of the government spending multiplier. The long-term real interest rate is measured in quarterly percentage points, while public debt is measured relative to quarterly GDP.

VAR innovations

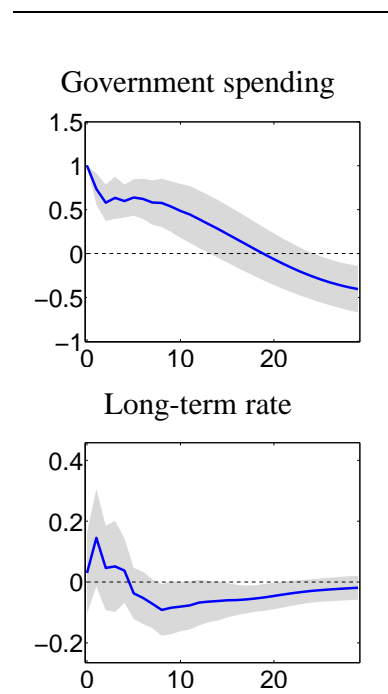

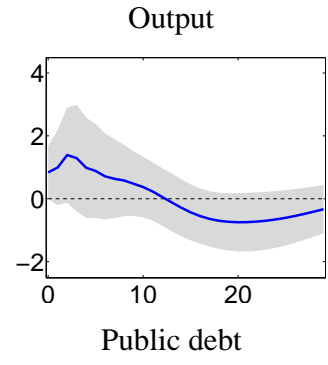

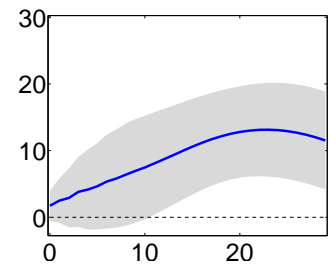

Forecast errors
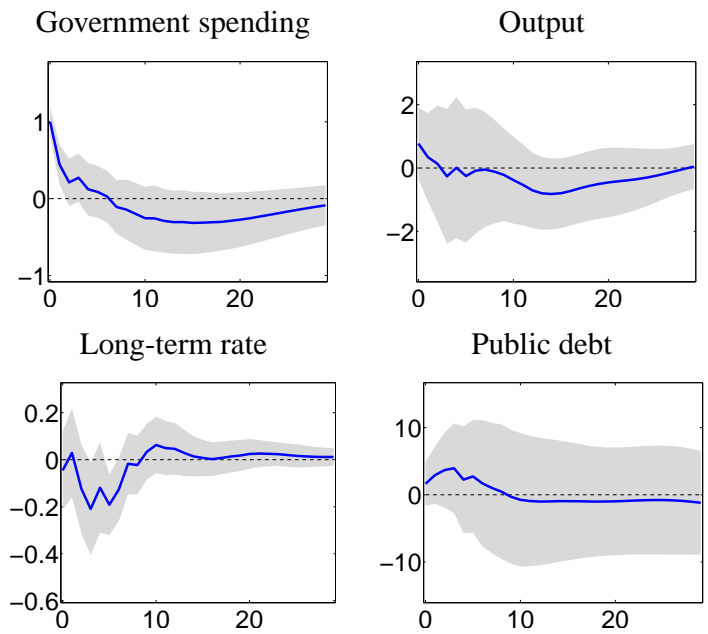

Figure 6: Effects of US government spending shock on US variables. Notes: the left column shows results for Blanchard-Perotti identification scheme, the right column shows results for forecast error identification scheme. The shock is normalized so that government spending increases by one percent of GDP on impact. Horizontal axis measures quarters. Solid lines display point estimates, shaded areas indicate 90 percent confidence bounds. Output and government spending are measured in percent of trend output, long-term rate measures the long-term real interest rate in quarterly percentage points, public debt is measured relative to quarterly GDP.

A Comparison of the graphs in the two columns shows that, while the responses are quantitatively different, their pattern is remarkably similar overall. ${ }^{9}$ Government spending, displayed in the first row,

\footnotetext{
${ }^{8}$ In this figure we show results pertaining to US variables obtained from a VAR model which also includes the US-EA exchange rate and EA output. We discuss results for these variables below.

${ }^{9}$ Ramey (2011) stresses a number of differences, notably in the responses of consumption and the real wage. We do not
} 
rises on impact, but its increase is not persistent. Under both identification schemes, spending actually tends to undershoot its long-run trend - this happens somewhat earlier under the identification scheme based on forecast errors (see Corsetti et al. 2011c). The response of output is positive on impact in both cases. However, while output displays a hump-shaped adjustment path under the identification scheme based on VAR innovations, its response is more short-lived when we use forecast errors to identify shocks. Regarding long-term real interest rates, we find a decline in the medium term following the shock. Finally, public debt rises strongly under both identification schemes, although the response is barely significant under the forecast-error approach.

While output multipliers are non-negative, it is worth noting here that the effects are moderate and short-lived. Hence, they are not suited to strengthen the case for extensive fiscal stimulus measures. Yet this evidence reflects merely the average effect of fiscal policy for a sample in which the economy arguably operated close to full employment and financial market were functioning reasonably well. The effectiveness of fiscal policy, in contrast, may be quite different under other circumstances. Elsewhere, indeed, we have shown that average linear estimates may hide strong differences across economic environments (see Corsetti et al. 2011b).

\subsubsection{External and cross-border effects}

In Figure 7 we turn to our analysis of the external effects of US government spending. As already mentioned, we compute the impulse responses in the figure, by rotating the bilateral variables, one at a time, as the last variable in the VAR model - with the exception of the real exchange rate, which is always included. The trade variables pertain to bilateral US variables and are measured in percent of US trend output. Output in the EA and the UK is instead measured in percentage deviation from trend.

The first row in the figure shows the response of the bilateral real exchange rate, which depreciates sharply and substantially, along a hump-shaped adjustment path. Although puzzling in light of the received wisdom, similar results have been documented for the US real effective exchange rate by Kim and Roubini (2008) and several subsequent studies.

The second and third rows display the dynamics of US exports and imports, respectively. Exports hardly move on impact, and start to improve over time. Overall, the increase is moderate, reaching a peak of about 0.15 and 0.05 percent of US trend output for the EA and UK as trading partner, respectively. Import responses differ somewhat across identification schemes, but movements in this variable are quite contained and barely significant. As a result, the US trade balance, especially against the EA, moves quickly into surplus after the first couple of quarters, as shown the forth row of the figure. This finding is in line with earlier studies providing evidence at odds with the notion of

include these variables in our model. Corsetti et al. (2011c) provide a more detailed discussion of similarities and differences across both identification schemes. 
VAR innovations
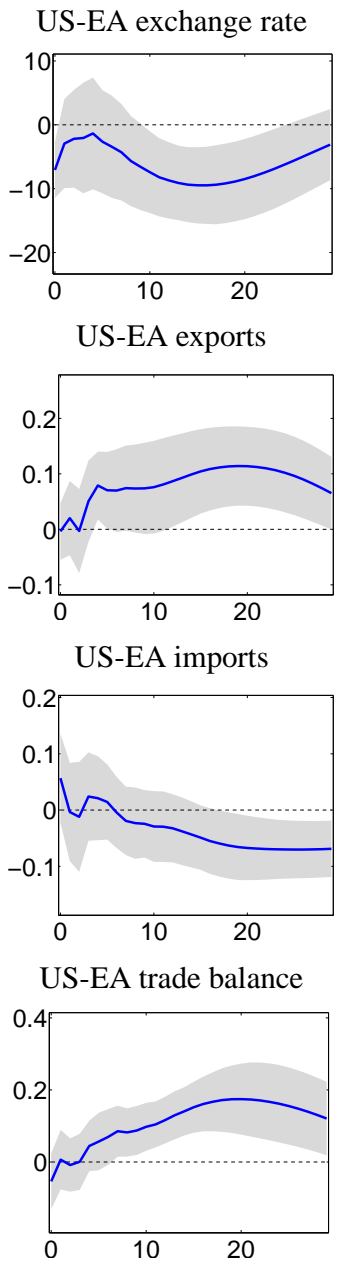

EA output

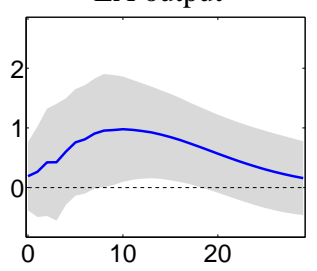

US-UK exchange rate

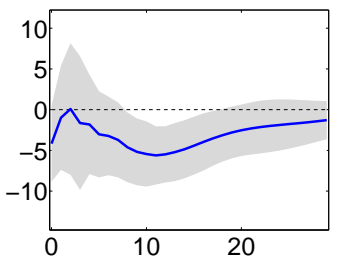

US-UK exports

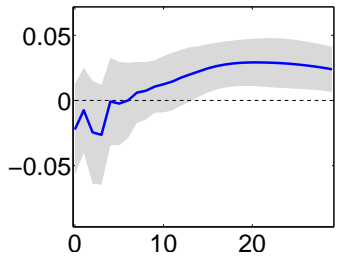

US-UK imports

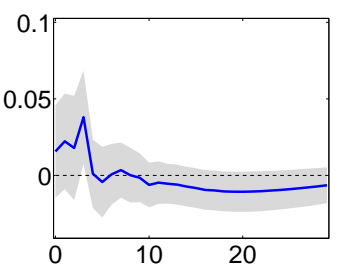

US-UK trade balance

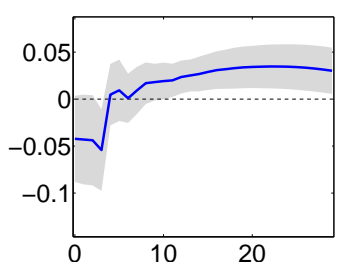

UK output

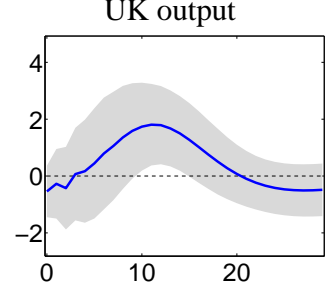

Forecast errors

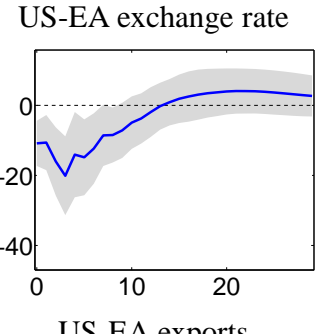

US-UK exchange rate

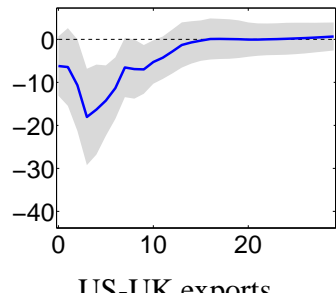

US-UK exports

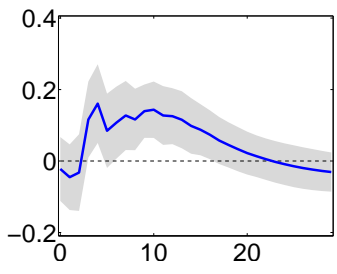

US-EA imports

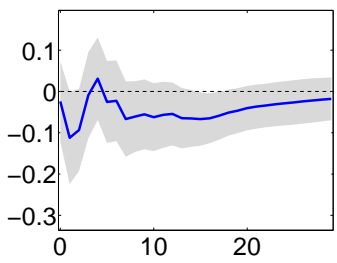

US-EA trade balance
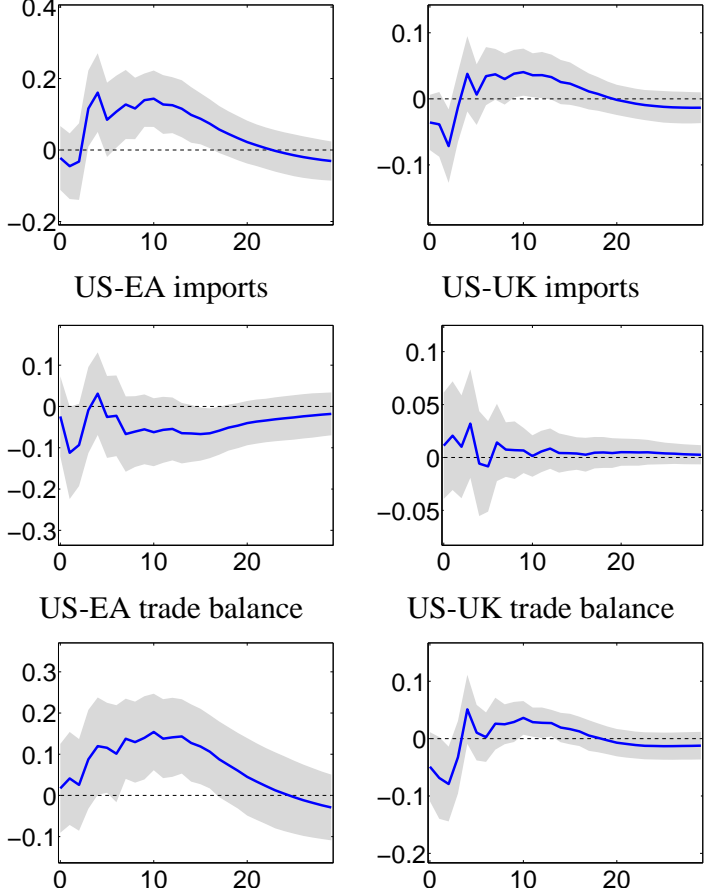

US-UK imports

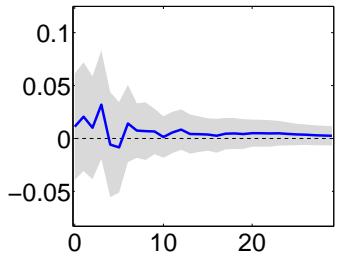

US-UK trade balance
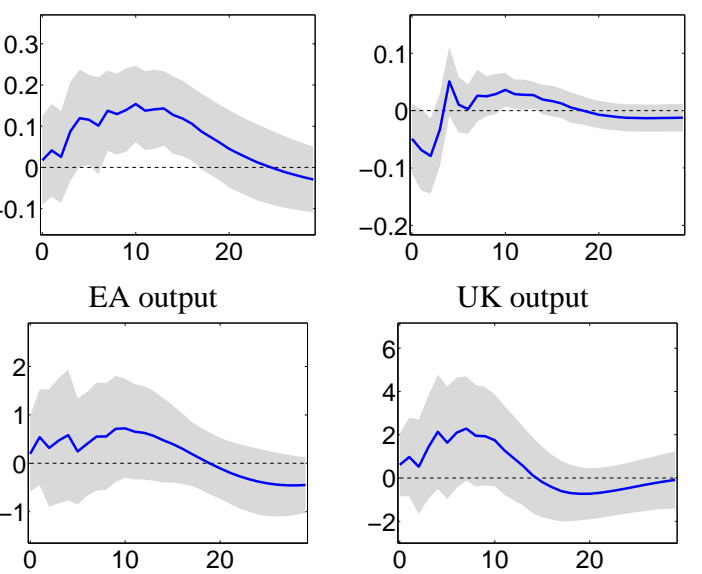

Figure 7: Effects of US government spending shock on bilateral trade with EA and UK and on EA and UK output. Notes: see figure 6; except for EA and UK output (measured in percentage deviation from trend), variables pertain to the US and are measured in bilateral terms in percent of US trend output.

"twin deficits" (see Kim and Roubini (2008), but also Corsetti and Müller (2006) and Monacelli and Perotti (2006) for different findings on the basis of alternative specifications and different samples). Finally, the bottom row of Figure 7 displays the response of output in the EA and the UK. The point estimate indicates a gradual, but sizable build-up, reaching at least 0.5 and 1 percent of EA and UK 
output, respectively. The response, however, is only marginally significant.

Results are similar both across identification schemes and across countries (EA or UK). At the country level, however, there are a few notable differences. The responses of exports and imports, as well as of the trade balance, are smaller in the UK case (although the response of US imports from the UK is positive on impact). UK output, in contrast, responds more strongly to the increase in US government spending although its adjustment pattern is quite similar to that of EA output.

Overall, the external effects of US spending shocks appear to be non-negligible. Empirical findings of substantial cross-border effects are not unusual. For instance, Beetsma and Giuliodori (2011) estimate sizeable cross-border effects of fiscal policy within Europe: in response to an exogenous increase in government spending in either France, Germany, Italy, Spain or the UK, the rest-of-EU output increases by about 0.35 percent, after 3 years. ${ }^{10}$

VAR innovations

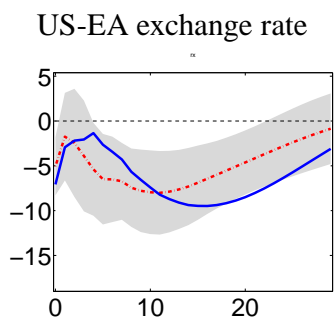

US-UK exchange rate

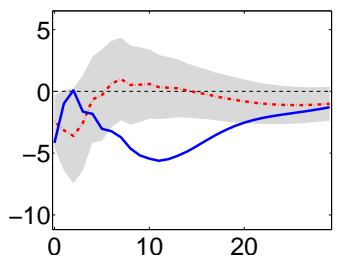

EA output

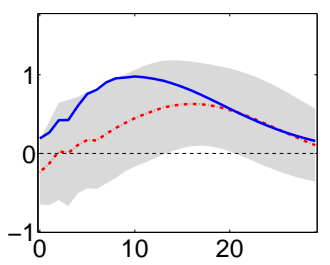

UK output

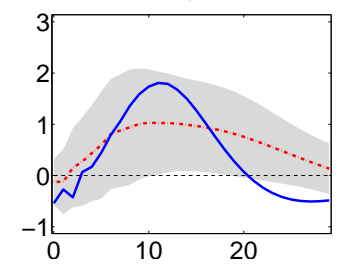

Forecast errors

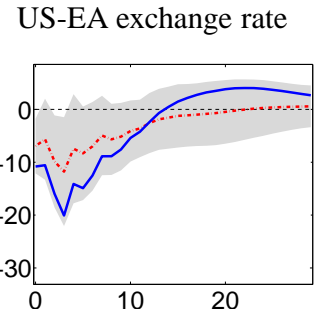

US-UK exchange rate

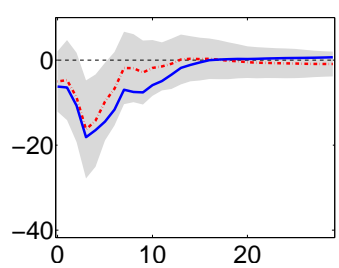

EA output

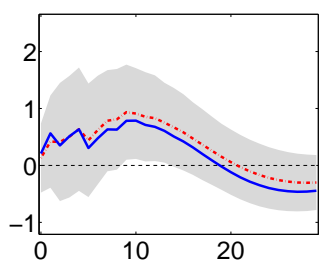

UK output

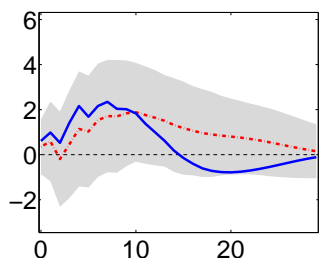

Figure 8: Effects of US government spending shock on real exchange rates and foreign output. Notes: see figure 6. Solid lines reproduce point estimates for baseline specification. Dashed-dotted lines (shaded areas) show point estimates (confidence bonds) for VAR model where US government spending is expressed relative to government spending in the EA (top) and UK (bottom).

It is worth stressing that the estimated dynamic cross-border effects of fiscal policy may reflect possible reactions by foreign policies. For instance, if government spending in the UK and the EA rises in response to a positive innovation to US spending, the cross-border dynamic effects shown in the figure may simply reflect the endogenous expansionary policy in the foreign economies. Strictly speaking, policy spillovers are defined holding constant the policy instruments abroad.

\footnotetext{
${ }^{10}$ In an early VAR analysis, Canzoneri et al. (2003), employing a variant of the Blanchard-Perotti identification scheme, also find a delayed, but sizeable increase in French, Italian and British output in response to US fiscal expansions. Beetsma et al. (2006) combine a VAR model with an estimated trade equation for European countries, and find sizeable output spillovers from shocks to German and French government spending.
} 
As a way to verify the robustness of our results, we thus consider an alternative VAR model and include US government spending in relative terms, that is, US spending relative to either UK or EA government spending. Figure 8 show results for the key variables of interest, again for both identification schemes discussed above. The dashed line report the point estimates together with 90 percent confidence bounds (grey area); solid lines, in contrast, show the point estimates for the baseline case. Results are quite similar to our baseline specification, especially for the forecast-error specification. Cross-border effects are slightly muted, however, for the Blanchard-Perotti specification. Incidentally, in the latter case, the puzzling depreciation of the real exchange rate vis-à-vis the UK disappears over the medium run.

In summary, the time-series evidence, subject to a number of important caveats common to timeseries studies on the fiscal transmission mechanism, we observe that our results lend some support to the notion that fiscal policy has consequential spillovers across borders, a view often voiced in policy circles. According to our point estimates, a US spending expansion of one percent of US output, can raise GDP in the UK up to a full percentage point of UK output. This result is particularly remarkable, given that the impact of the US expansion on US output is contained to start with. However, contrary to the widespread view in policy circles, the transmission mechanism does not appear to work through an international trade channel. US imports from the EA hardly move in response to a US spending shock; imports from the UK only respond on impact. US exports actually rise over time, after a deterioration on impact of exports to the UK. In the next section, we will resort to theory in order to shed light on the underlying transmission channels.

\subsection{A quantitative business cycle model}

To gain insight on the international transmission of fiscal policy, we resort to a two-country business cycle model. Since our goal is to provide a close up analysis of transmission, we abstract from a number of economic features, which are not essential for our argument. In particular, we use a simplified version of the model in Corsetti et al. (2011c), as we abstract from investment demand and capital accumulation. As the basic features of the model are standard, we will keep the model outline brief. Instead, we will highlight those equilibrium relationships which are pivotal to the international transmission mechanism. We will also discuss to what extent and under which assumptions the predictions of the model are qualitatively in line with the VAR evidence (including the evidence of a limited role for the trade channel conventionally defined). Quantitatively, however, we will show that the spillover effects in the model turn out to be smaller than in the empirical analysis. 


\subsubsection{Model outline}

The model we employ has become a standard work-horse in macroeconomics, providing the theoretical core to large policy models adopted by policy institutions. The model economy includes two countries, referred to as $H$ (Home) and $F$ (Foreign), each producing a variety of country-specific intermediate goods, with the number of intermediate good producers normalized to unity. A fraction $n$ of firms is located in Home, the remaining firms $(n, 1]$ is located in Foreign. Analogously, Home accounts for a fraction $n \in[0,1]$ of the global population. Intermediate goods are traded across borders, while final goods, which are bundles of intermediate goods, are not. Households supply labor services only within the country where they reside, but trade a complete set of state-contingent assets internationally. The model allows for nominal rigidities. Prices of intermediate goods are sticky in producer-currency terms. Likewise wages are also adjusted infrequently. Below, we focus our exposition on Home. When necessary, we refer to foreign variables by means of an asterisk.

Households and firms Households supply differentiated labor services. Within each country, they are indexed according to labor types on the unit interval as in Erceg et al. (2000). Households engage in monopolistic competition, but their ability to set wages is restricted: in each period only an exogenously determined fraction $\left(1-\xi_{W}\right)$ of households may adjust their wage. Differentiated labor services $H_{t}(h), \in[0,1]$ are bundled into aggregate labor services according to the following technology

$$
H_{t}=\left(\int_{0}^{1} H_{t}(h)^{\frac{\nu-1}{\nu}} d h\right)^{\frac{\nu}{\nu-1}} .
$$

Letting $W_{t}(h)$ denote the wage rate for labor services of type $\mathrm{h}$, the unit cost of domestic labor services, i.e. the aggregate wage index, is given by

$$
W_{t}=\left(\int_{0}^{1} W_{t}(h)^{1-\nu} d h\right)^{\frac{1}{1-\nu}} .
$$

Optimal bundling of differentiated labor services implies the demand function

$$
H_{t}(h)=\left(\frac{W_{t}(h)}{W_{t}}\right)^{-\nu} H_{t} .
$$

Households consume a bundle of intermediate goods, which are assembled in order to minimize expenditures given a specific aggregation technology. Let $A_{t}$ and $B_{t}$ denote bundles of domestically produced and imported intermediate goods, respectively, the consumption bundle is defined as follows

$$
\begin{aligned}
C_{t} & =\left[(1-(1-n) \omega)^{\frac{1}{\sigma}} A_{t}^{\frac{\sigma-1}{\sigma}}+((1-n) \omega)^{\frac{1}{\sigma}} B_{t}^{\frac{\sigma-1}{\sigma}}\right]^{\frac{\sigma}{1-\sigma}} \\
C_{t}^{*} & =\left[(n \omega)^{\frac{1}{\sigma}}\left(A_{t}^{*}\right)^{\frac{\sigma-1}{\sigma}}+(1-n \omega)^{\frac{1}{\sigma}}\left(B_{t}^{*}\right)^{\frac{\sigma-1}{\sigma}}\right]^{\frac{\sigma}{1-\sigma}}
\end{aligned}
$$


where $\sigma$ measures the terms of trade elasticity of the relative demand for domestically produced goods, and $\omega \in[0,1]$ provides a measure for home bias. ${ }^{11}$

The bundles of domestically produced and imported intermediate goods, in turn, are defined as follows

$$
A_{t}=\left[\left(\frac{1}{n}\right)^{\frac{1}{\epsilon}} \int_{0}^{n} A_{t}(j)^{\frac{\epsilon-1}{\epsilon}} d j\right]^{\frac{\epsilon}{\epsilon-1}}, B_{t}=\left[\left(\frac{1}{1-n}\right)^{\frac{1}{\epsilon}} \int_{n}^{1} B_{t}(j)^{\frac{\epsilon-1}{\epsilon}} d j\right]^{\frac{\epsilon}{\epsilon-1}},
$$

where $A_{t}(j)$ and $B_{t}(j)$ denote intermediate goods produced in $H$ and $F$, respectively, and $\epsilon$ measures the elasticity of substitution between intermediate goods produced within the same country.

Letting $P(j)$ denote the price of an intermediate good expressed in domestic currency and $\mathcal{E}_{t}$ the nominal exchange rate (the price of domestic currency in terms of foreign currency) we assume that the law of one price holds, so that $P^{*}(j)=\mathcal{E}_{t} P(j)$. Price indices are given by

$$
\begin{gathered}
P_{A t}=\left[\frac{1}{n} \int_{0}^{n} P_{t}(j)^{1-\epsilon} d j\right]^{\frac{1}{1-\epsilon}}, P_{B t}=\left[\frac{1}{1-n} \int_{n}^{1} P_{t}(j)^{1-\epsilon} d j\right]^{\frac{1}{1-\epsilon}}, \\
P_{t}=\left[(1-(1-n) \omega) P_{A t}^{1-\sigma}+((1-n) \omega) P_{B t}^{1-\sigma}\right]^{\frac{1}{1-\sigma}}, \\
P_{t}^{*}=\left[n \omega\left(P_{A t}^{*}\right)^{1-\sigma}+(1-n \omega)\left(P_{B t}^{*}\right)^{1-\sigma}\right]^{\frac{1}{1-\sigma}},
\end{gathered}
$$

and $Q_{t}=P_{t} \mathcal{E}_{t} / P_{t}^{*}$ measures the real exchange rate.

Given the above definitions and results, we can write the household's utility functional as follows

$$
E_{t} \sum_{s=0}^{\infty} \beta^{s}\left(\ln C_{t+s}(h)-\vartheta \frac{H_{t+s}(h)^{1+\varphi}}{1+\varphi}\right),
$$

where $\beta$ is the discount factor, $\vartheta$ is a constant determining labor supply in steady state, and $\varphi$ is the inverse of the Frisch elasticity of labor supply.

We assume that households trade a complete set of state-contingent securities. ${ }^{12}$ Let $\Xi_{t+1}(h)$ denote the payoff in units of currency $\mathrm{H}$ in period $t+1$ of the portfolio held by household $h$ at the end of period $t$. With $\rho_{t, t+1}$ denoting the stochastic discount factor, the budget constraint of the household is given by

$$
W_{t}(h) H_{t}(h)+R_{t} K_{t}(h)+\Upsilon_{t}-T_{t}-P_{t}\left(C_{t}(h)+X_{t}(h)\right)=E_{t}\left\{\rho_{t, t+1} \Xi_{t+1}(h)\right\}-\Xi_{t}(h),
$$

where $T_{t}$ and $\Upsilon_{t}$ denote lump-sum taxes and profits of intermediate good firms, respectively. Both are levied/distributed equally across households.

\footnotetext{
${ }^{11}$ This specification follows Sutherland (2005) and De Paoli (2009). With $\omega=1$, there is no home bias: if the relative price of foreign and domestic goods is unity, the fraction of domestically produced goods which ends up in the consumption bundle is equal to $n$, while imports account for a share of $1-n$. Importantly, consumption goods are identical across countries in this case. A lower value of $\omega$ implies that the fraction of domestically produced goods in consumption goods exceeds the share of domestic production in the world economy. If $\omega=0$, there is no trade in goods across countries.

${ }^{12}$ Assuming alternatively incomplete international financial markets, allowing for trade in non-contingent debt only, has little bearing on our results. Results are available on request.
} 
Under complete financial markets, households fully insure against the idiosyncratic income risk that results from their limited ability to adjust wages in each period. Households are, therefore, homogeneous with respect to consumption and asset holdings. By contrast, households are heterogeneous with respect to labor supply as a result of infrequent wage adjustments. Given the household's marginal utility of nominal income, $\Lambda_{t}$, a household that is allowed to reoptimize its wage sets $\tilde{W}_{t}(h)$ to meet the following objective

$$
\max E_{t} \sum_{s=0}^{\infty}\left(\beta \xi_{W}\right)^{s}\left[\Lambda_{t+s} H_{t+s}(h) \tilde{W}_{t}(h)-\vartheta \frac{H_{t+s}(h)^{1+\varphi}}{1+\varphi}\right],
$$

subject to the demand for its labor service (3).

Producers of differentiated intermediate goods engage in monopolistic competition. The production function is given by $Y_{t}(j)=H_{t}(j)$, where $H_{t}(j)$ denotes domestic labor services employed by firm $j \in[0, n]$ in period $t$. We assume that prices are set in the currency of the producer and that price setting is constrained exogenously à la Calvo, so that in each period only a fraction of intermediate good producers $\left(1-\xi_{P}\right)$ may adjust its price. When firm $j$ has the opportunity, it sets $\tilde{P}_{t}(j)$ to maximize the expected discounted value of net profits:

$$
\max E_{t} \sum_{s=0}^{\infty} \frac{\xi_{P}^{t+s} \rho_{t, t+s} Y_{t+s}^{D}(j)}{P_{t+s}}\left[\tilde{P}_{t}(j)-W_{t+s}\right]
$$

subject to demand $Y_{t}^{D}(j)$.

Fiscal and monetary policy Government consumption is financed either through lump-sum taxes, $T_{t}$, or through the issuance of nominal debt, $D_{t}$, denominated in domestic currency. The period budget constraint of the government reads as follows

$$
\frac{D_{t+1}}{1+i_{t}}+T_{t}=D_{t}+G_{t}
$$

where $\left(1+i_{t}\right)$ is the gross return on a one-period nominally riskfree bond, which is equal to $1 / E_{t} \rho_{t, t+1} ; G_{t}$ denotes government spending which, under the baseline scenario, is a bundle isomorphic to private consumption, except that it falls only on domestically produced goods-reflecting the observation that the import content in government spending is considerably lower than in private spending (e.g. Corsetti and Müller 2006).

Define $D_{R t}=D_{t} / P_{t-1}$ as a measure for real beginning-of-period debt, and $T_{R t}=T_{t} / P_{t}$ as taxes in real terms. Letting variables without time subscript refer to steady-state values, we specify the following feedback rules

$$
G_{t}=(1-\rho) G+\rho G_{t-1}-\psi_{G} D_{R t}+\varepsilon_{t}, \quad T_{R t}=\psi_{T} D_{R t},
$$


where $\varepsilon_{t}$ represents an exogenous iid shock to government spending. The $\psi$-parameters, which we posit to be non-negative throughout, capture a systematic feedback of public debt on government spending (negative) and taxes (positive). We assume that either parameter is sufficiently large to ensure the non-explosiveness of public debt. For instance, if $\psi_{G}=0$ we posit that taxes are raised sufficiently strongly in response to higher outstanding debt. Note, however, that $\psi_{G}=0$ implies Ricardian equivalence, so the specific time path of taxes, for a given time path of government spending, is irrelevant for the real allocation in the economy. This assumption is frequently made in analyses of fiscal transmission; by relaxing the assumption and allowing for a feedback channel from debt to government spending, we allow for richer and arguably more plausible dynamics of government spending (see also Corsetti et al. (2011c)).

Finally, turning to monetary policy, we assume flexible exchange rates and specify policymaking by means of a forward-looking interest rate feedback rule:

$$
\ln \left(1+i_{t}\right)=\phi_{\Pi} \Pi_{A t+1}
$$

where $\Pi_{A t}=P_{A t} / P_{A t-1}$ measures domestic (producer price) inflation.

Equilibrium To carry out our analysis, we consider a linear approximation of the model's equilibrium conditions around a deterministic steady state in which government debt and inflation are zero and trade is balanced. Before turning to simulation results, it is useful to focus first on the equilibrium conditions which play a critical role in shaping the international transmission mechanism. Regarding notation, for each variable we will use lower-case letters to denote deviations from steady state. Private expenditure is governed by the Euler equation, which, solving forward and assuming a stationary economy, implies

$$
c_{t}=\frac{1}{\gamma} \sum_{k=0}^{\infty} \underbrace{\left(i_{t+k}-\pi_{t+1+k}\right)}_{\equiv r r_{t+k}},
$$

where $\pi_{t}$ measures CPI inflation. Equilibrium condition (17) ties the current level of consumption demand (in terms of deviations from steady state) to the entire path of expected future short-term real interest rates, $r r_{t}$. By the expectations hypothesis, in turn, the latter is equivalent to the real rate of return on a bond of infinite duration (see, for example, Woodford 2003, p. 244), or the long-term real interest rate for short.

As stressed in Corsetti et al. (2011c), movements in long-term interest rates are at the heart of the transmission mechanism through which fiscal and monetary policy influence aggregate demand. An obvious consideration is that long-term rates reflect more than the contemporaneous stance of these policies, as they heavily depend on expectations about the future policy course. They "telescope", so 
to speak, anticipated future policy changes into today's financial conditions. By way of example, if households come to expect tight fiscal policy over the medium run, they anticipate correspondingly lower future policy rates. All else equal, these translate into an upfront drop in long-term rates, boosting current consumption. The opposite is true if households anticipate a combination of loose fiscal and tight monetary policy to prevail in the future. This - essentially financial - transmission channel substantiates the classical claim that, while current fiscal retrenchment can be expected to be contractionary, anticipations of future cuts are actually expansionary in the short run.

Moreover, it is easy to show that the exchange rate appreciation depends linearly on the Home-toForeign differential in long-term real interest rate: this simply follows from combining Euler equations for bonds traded in domestic and foreign currency, and solving forward. In equilibrium, the price for Home consumption rises relative to Foreign consumption - the exchange rate strengthens in real terms - whenever long-term rates at home exceed those abroad (see Corsetti et al. 2011c).

To interpret our results below, it is instructive to rewrite the short-term real interest rate as follows

$$
\begin{aligned}
r r_{t} & =i_{t}-E_{t} \pi_{t+1}=i_{t}-\left((1-(1-n) \omega) E_{t} \pi_{A, t+1}+(1-n) \omega E_{t} \pi_{B, t+1}\right) \\
& =(1-(1-n) \omega)\left(i_{t}-E_{t} \pi_{A, t+1}\right)+(1-n) \omega\left(i_{t}^{*}-E_{t} \pi_{B, t+1}^{*}\right) .
\end{aligned}
$$

The first equivalence follows from the fact that Home inflation has a domestic and an importedgoods-prices component, which is in turn driven by movements in the exchange rate. The second equivalence is a by-product of uncovered interest parity, stating that Home nominal rates are approximately identical (up to first order) to Foreign nominal rates, plus the expected rate of currency depreciation.

The above expression shows that (under uncovered interest parity and the law of one price for intermediate goods traded internationally) short-term real interest rates are a weighted average of the difference between policy rates and domestic inflation, in the Home and the Foreign country. This relationship highlights that monetary and fiscal policy in one country affect the short-term real interest rate in the other country. The relative weight of foreign policy on domestic rates is determined by $(1-n) \omega$, which reflects the average import share in consumption and thus the openness of the economy. ${ }^{13}$

In summary, the long-term rate, in turn a function of current and anticipated future short rates, drives the response of the private sector demand to temporary (fiscal) shocks. The equilibrium relationships (17) and (18) constitute a financial channel through which both domestic and foreign, current and expected future monetary and fiscal policy impact on the long-term real interest rate. It affects both the domestic and external components of demand - interest and exchange rates interact in equilibrium,

\footnotetext{
${ }^{13} \mathrm{By}$ virtue of the forward-looking nature of the consumption decision, the fact that both the uncovered interest parity and the law of one price may fail in the short run is not a fundamental objection to this transmission channel. What ultimately matters is whether both laws hold in the medium and long-run.
} 
depending, among other parameters, on intra-temporal and intertemporal elasticities of substitution.

\subsubsection{Calibration}

In order to solve the model numerically, we assign the following parameter values. A period in the model corresponds to one quarter. Accordingly, we set $\beta=0.99$. For the Frisch elasticity of labor supply we assume a value of one-third by setting $\varphi=3$; see Domeij and Flodén (2006) for recent evidence. Given these assumptions, we set $\vartheta$ to ensure that agents spend on average one-third of their time endowment working. The trade price elasticity $\sigma$ is set equal to 0.5 in the baseline scenario, a value well within the (admittedly wide) range considered in the recent macroeconomic literature; see Corsetti et al. (2008) for further discussion. Regarding $\gamma$, the coefficient of relative risk aversion, we assume a value of 0.26 , in line with the estimates of Amato and Laubach (2003), but somewhat higher than the estimates by Rotemberg and Woodford (1997). This implies nevertheless a fairly high value for the intertemporal elasticity of substitution (IES) of private expenditure, as we do not model private investment explicitly. Nominal rigidities play a key role in the transmission of government spending shocks. We assume that $\xi_{P}=0.66$, implying an average price duration of three quarterswithin the range of values discussed, for example, by Nakamura and Steinsson (2008). Regarding wage rigidities we set $\xi_{W}=0.75$ so that the average wage duration is four quarters. For monetary policy we assume $\phi_{\pi}=1.5$.

The steady-state output share of government spending is assumed to be 20 percent. The parameter $\rho$ is set to 0.9 , capturing the persistence of government spending deviations from trend documented by many VAR studies on US data. In our baseline scenario we set $\psi_{G}=\psi_{T}=0.02$, implying a systematic feedback from higher public debt to government spending and taxes. These parameter values not only ensure debt-stabilizing fiscal policy over time, but also assign some role to spending restraint. Specifically, an initial increase in government spending would be followed after some time by a fall in spending below trend, in line with the VAR evidence. ${ }^{14}$

Finally, we consider two distinct trade scenarios which are meant to capture bilateral trade relationships between the US and either the EA or the UK, respectively. In the first one, the Foreign economy is only slightly smaller than the Home economy: we set $n=0.57$. Alternatively, we set $n=0.85$. In both cases, we set $\omega$ to target the import share of the foreign country, i.e., 19 and 28 percent, respectively (this implies an import share in Home of 14 and 4 percent, respectively). Note that, under these assumptions, spillovers will tend to be relatively large. An alternative approach would be to set

\footnotetext{
${ }^{14}$ Using annual observations to estimate spending and tax rules, Galí and Perotti (2003) report estimates for the coefficient on debt ranging from -0.04 to 0.03 for government spending, and from 0 to 0.05 for taxes, in a panel of OECD members (no breakdown by country provided). For the U.S., Bohn (1998) reports estimates for the response of the surplus to debt in a range from 0.02 to 0.05 . To see that our parameter choice ensures the solvency of the government, that is, that fiscal policy is "passive" in the sense of Leeper (1991), consider a linear approximation of the equilibrium conditions around the steady state: abstracting from autocorrelation of government spending and assuming an "active monetary policy", debt stability holds if $1-\psi_{G}-\psi_{T}<\beta$.
} 

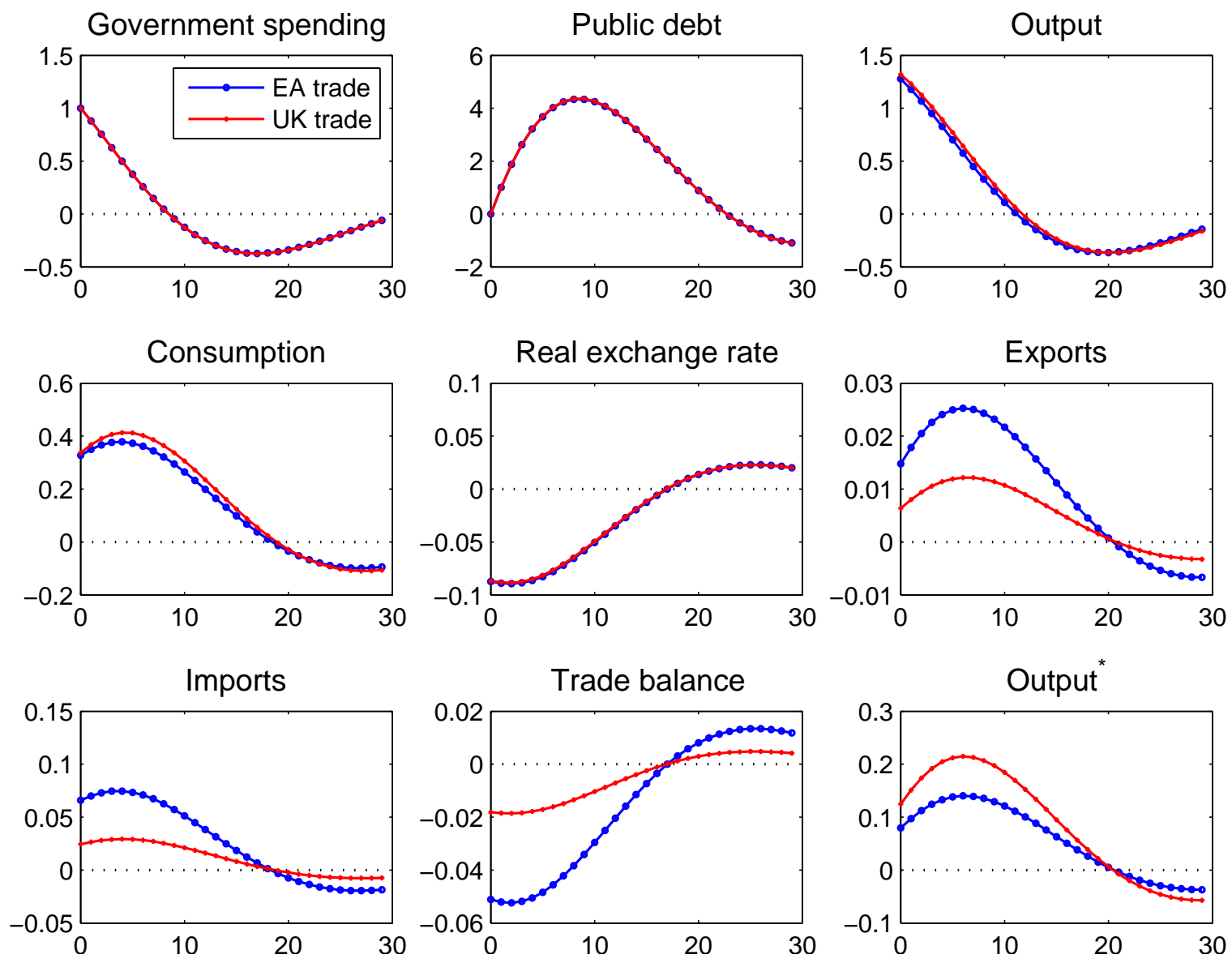

Figure 9: Effects of government spending shock in Home: baseline scenario (for given country size $n$, $\omega$ is set to target import share of EA (19 percent) and UK (28 percent), see blue lines with circles and red line with crosses, respectively). All variables pertain to Home (US) and are measured in output units, except for Output*. The real exchange rate is measured in percentage deviations from steady state.

the import share in Home so as to account for EA and UK imports in the US (about 2 and 1 percent, respectively). Under this approach, spillover effects would be virtually zero - although this possibly understates the actual effect, as spillovers from the US to the EA or the UK are likely to be transmitted also through third countries. However, below we will show that, for either set of assumptions, the model will not be able to match the size of the cross-border output effects estimated in our VAR analysis above.

\subsubsection{Simulation results}

Figure 9 shows results for the baseline specifications, displaying the impulse responses of selected variables to an exogenous increase in government spending in Home. Time is measured on the horizontal axis in quarters. The responses of quantities are measured in percent of domestic output - with 
the exception of foreign output, which is measured in percent of foreign output. The real exchange rate is measured in percentage deviations from steady state. The lines with circles (blue) reflect results for the US-EA trade specification ( $n=57$ and an import share in Foreign of 19 percent). Lines with crosses reflect results for the US-UK trade specification ( $n=85$ and an import share in Foreign of 28 percent).

Government spending increases initially because of the shock, but then tends to undershoot its longrun (steady-steady) state level appreciably between 10 and 30 quarters from the shock - the budget adjustment rule brings about a "spending reversal". In response to the shock there is a sizeable, humpshaped build-up of Home public debt. Home output increases sizably, with an impact response above unity. Home consumption, instead, shows a hump-shaped increase with a peak response of about 0.3 percent of output, after 8 quarters.

The real exchange rate depreciates on impact and stays below steady-state level for an extended period. Quantitatively, however, this response is contained relative to the VAR results. Home exports improve slightly in response to the innovation, but then move gradually into negative territory. Quantitatively, the responses are also quite moderate. Home imports, in turn, increase more sizably on impact and return gradually to steady state. The Home trade balance moves into a deficit for the first ten quarters, then improves after about 4 to 5 years. Trade balance movements are nonetheless small. Finally, the impact Foreign output is positive on impact and rises further, reaching a peak after about 10 quarters.

A few results from these exercises stand out. The responses pertaining to domestic developments in the Home country are virtually identical in both (US-EA or US-UK) specifications. There are however differences in the response of trade variables. Home exports and imports, as well as the trade balance tend to respond more in the US-EA trade scenario. Foreign output, in contrast, increases more strongly in the US-UK scenario.

Overall, the predictions of the model are broadly in line with the VAR evidence, discussed above, at least qualitatively. Nonetheless, international spillovers on foreign activity are small relative to the point estimates from the VAR model, especially as far as peak responses are concerned. Also, the pattern of the Home trade balance for the US-EA specification of the model is quite distinct from what we documented for the VAR model.

To shed further light on the mechanisms underlying these results, Figure 10 contrasts the responses for the US-EA trade baseline specification (blue lines with circles) with the responses obtained under the assumption that government spending falls on both domestic and foreign goods (black lines with diamonds) and under the assumption that the import share is 2 percent in Home (corresponding to the average import share of imports from the EA, in terms of US GDP); and 2.6 percent in Foreign (red line with crosses). 
Government spending
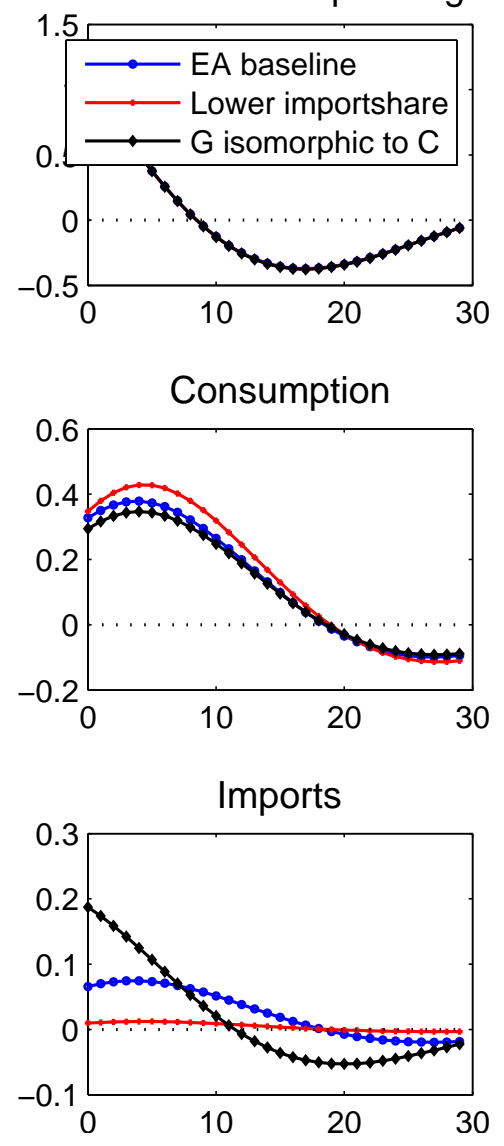

Public debt

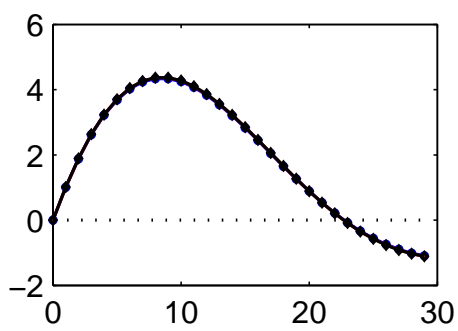

Real exchange rate
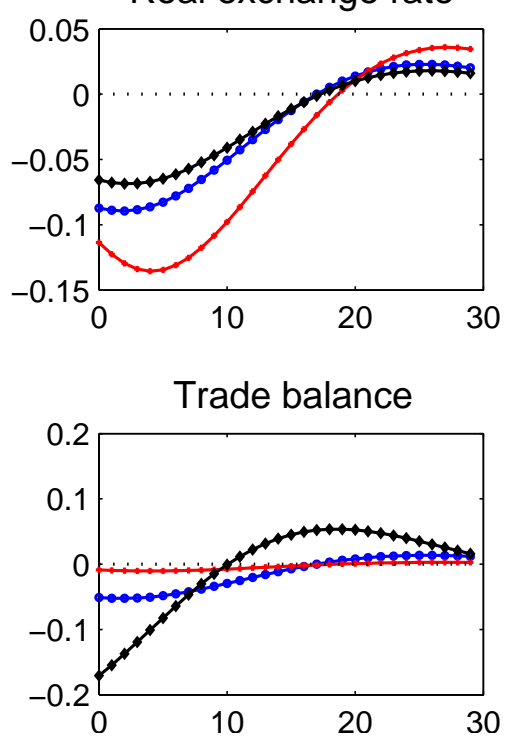

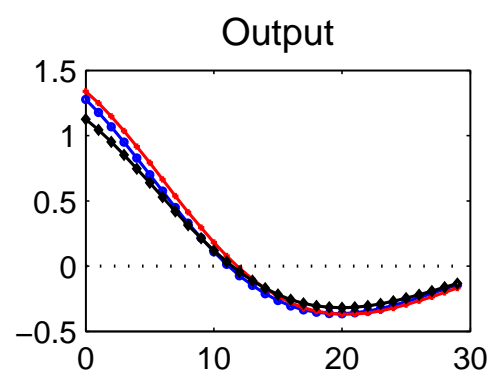

Exports

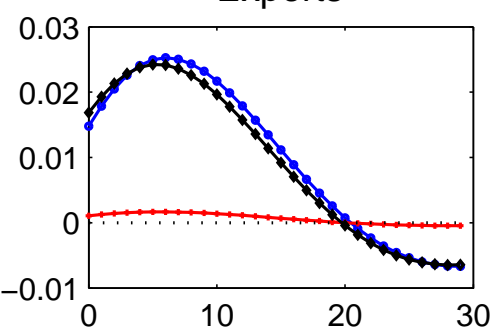

Output ${ }^{*}$

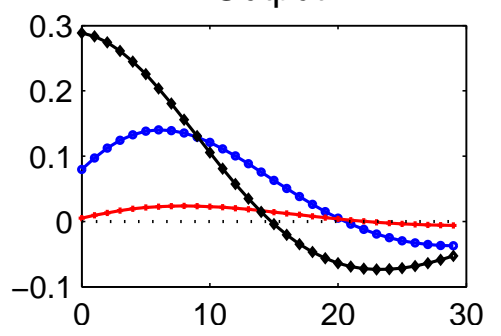

Figure 10: Effects of a government spending shock in the Home country: baseline model with US-EA trade scenario (blue lines with circles); alternative specifications with government spending falling on both domestic and foreign goods (black lines with diamonds) and imports in Home account for 2 percent of GDP (red lines with crosses). Notes: see figure 9. 

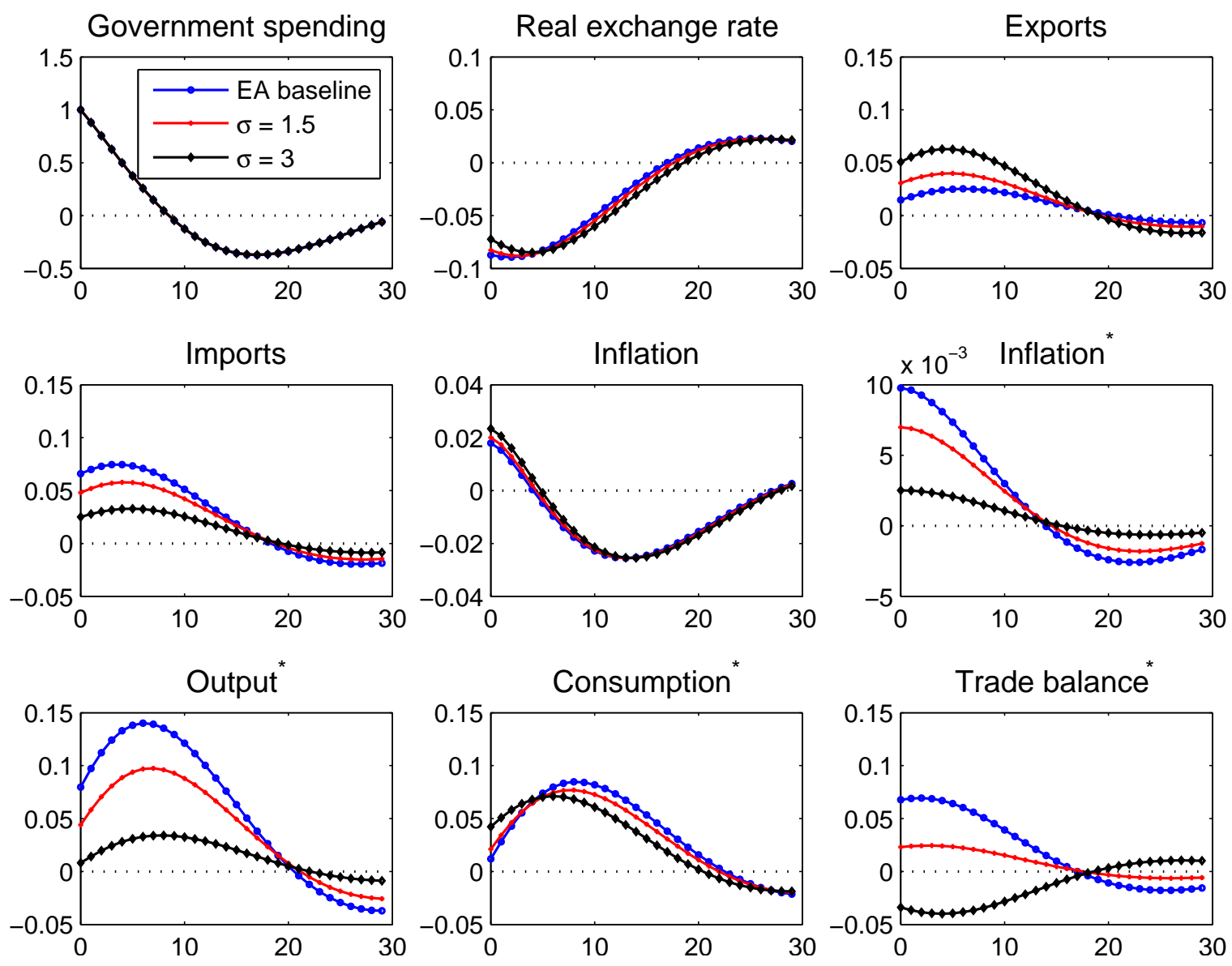

Figure 11: Effects of a government spending shock in the Home country: baseline specification for US-EA trade scenario (blue lines with circles); alternative specification with $\sigma=1.5$ (red lines with crosses) and $\sigma=3$ (black lines with diamonds). Notes: see figure 9.

Under these alternative assumptions, perhaps not surprisingly, trade variables respond quite differently, at least from a quantitative point of view. Consider first the case of a low import share in the Home country. In this case there is virtually no effect of a Home fiscal expansion on Home trade variables, measured in terms of Home output. Foreign output also appears basically unaffected. If, instead, the import share is left unchanged relative to the baseline scenario, but we assume that government spending falls on goods produced in both the Home and the Foreign country, spill-over effects are stronger. Notably, the impact responses of Home imports, the Home trade balance and Foreign output are much stronger than in the baseline scenario, reflecting the direct effect of increased government spending in Home on goods produced abroad. 


\subsubsection{A close-up analysis of spillovers}

As we are particularly interested in the mechanism underlying international spillovers, it is appropriate to provide a detailed account on the adjustment process in the Foreign country, when the Home government undertakes a fiscal expansion. Under our baseline scenario, Figure 11 shows the response of Foreign output, consumption and trade balance. Since our baseline assumes a relatively small value for the trade price elasticity, we also report responses assuming higher values for $\sigma=\{1.5,3\}$, displayed by the red lines with crosses and the black lines with diamonds, respectively.

The model's predictions are sensitive to these alternative assumptions, especially as far as crossborder effects are concerned. As the real exchange depreciates, demand shifts, all else equal, towards goods produced in Home. This is reflected by rising Home exports. Such an effect is stronger, the higher the trade price elasticity. For high values of this elasticity, indeed, the increase in Home exports dominates the increase in Home imports (which is driven by the increased level of Home activity), and the Foreign trade balance moves into a deficit. As a result, spillovers from the Home fiscal expansion on Foreign output are also somewhat weaker relative to the baseline scenario.

Yet, these results qualify the widespread view that spillover effects operate exclusively or mostly through the trade balance. As already discussed in relation to the expressions (17) and (18), the level of private expenditure is tightly linked to long-term real rates, that is, it is pinned down by an asset price. Since these rates reflect the entire path of current and anticipated future short-term real rates, they are in turn driven by the dynamics of domestic (producer price) inflation in Home and Foreign (affected by fiscal variables), and by the corresponding adjustment of policy rates by the central banks. In our experiments, anticipations of spending reversals lead private agents to foresee a low domestic inflation and, as the Home monetary stance is consistent with an interest rate feedback rule, a path of low short-term real rates (see Corsetti et al. 2011c for a detailed discussion). This, all else equal, drives down long-term real interest rates, suggesting that spending reversal cause (other things equal) a short-run expansion in demand (the larger, the sooner the expected reversal is phased-in).

From the vantage point of the Foreign country, the dynamics of Home inflation and Home monetary policy have a direct bearing on the domestic long-term real interest rate. It is through this financial channel, that domestic fiscal policies generate sizeable international spillover effects. In our experiment, the Foreign long-term rate falls gradually over time, in anticipation of the approaching reversal at Home. This drives the dynamic adjustment of Foreign consumption, which rises in a hump-shaped manner in response to the Home fiscal expansion.

This is not to deny that openness and trade matter for the international transmission mechanism. Depending on the trade price elasticity, the Foreign trade balance may improve or worsen in response to a Home fiscal expansion, thus affecting the magnitude of the cross-border effects. But Foreign output and consumption still rise, irrespectively of the sign of the trade balance response. Yet the 
degree of trade integration also matters for the strength of the financial channel, as trade openness, other things equal, magnifies the role of foreign policy rates for domestic real interest rates (a point emphasized by our analytical derivation of (17) and (18) above). In our baseline scenario, for instance, the positive impact spillover on output raises Foreign inflation and thus the Foreign policy rate. Yet consumption increases relative to steady state; this is in line with the anticipated spending reversals in Home - reflected in declining Foreign long-term real interest rates.

\subsubsection{The policy framework}

So far we have discussed simulation results against the background of the VAR evidence, which captures the average effect of government spending innovations over the entire sample period. We have shown that the model predictions align well with the evidence along various dimensions and identified dimensions in which the model fails quantitatively. In doing so, we have also identified channels through which domestic fiscal policy measures are likely to spill over onto other countries. Specifically, the hump-shaped increase of Foreign output in response to a Home fiscal expansion is driven by the dynamics of long-term real interest rates.

In our baseline model, however, the specific dynamics of the long-term real rate - especially its decline in response to a fiscal innovation - is the result of modeling a fiscal and monetary policy mix which gives rise to spending reversals and a moderate response to inflation by the Central Bank, according to a standard Taylor rule (see Corsetti et al. 2011c). In the following, we discuss further the role of the policy framework.

To start with, Figure 12 displays the dynamic adjustment to a Home fiscal expansion in our baseline scenario, and under an alternative scenario. For the latter we assume that government spending follows an exogenous $\operatorname{AR}(1)$ process, as is commonly posited in the literature $\left(\psi_{G}=0\right)$. Put differently, we now abstract from a budget policy rule which relates public debt accumulation to both tax and spending adjustment over time.

The difference in the results across the two specifications is quite stark. In the absence of a spending reversal, the Home real exchange rate appreciates and the Home long-term real rates rise (not shown), causing Home consumption to decline (not shown). This leads to a fall in Home imports (not shown), and (although Home exports also fall because of real appreciation), an improvement in the Home trade balance. Relative to the baseline scenario, the medium-term policy mix at Home differs considerably. This impacts - via the financial transmission channel - on Foreign too. In particular, Foreign consumption declines. This is consistent with a rise in the Foreign long-term rate reflecting the current and future fiscal-monetary stance at Home in the absence of a spending reversal. Overall, we note that absent a spending reversal, the model predictions are at odds with the VAR evidence along various dimensions. Most importantly, the output spillovers are negative in this case. 

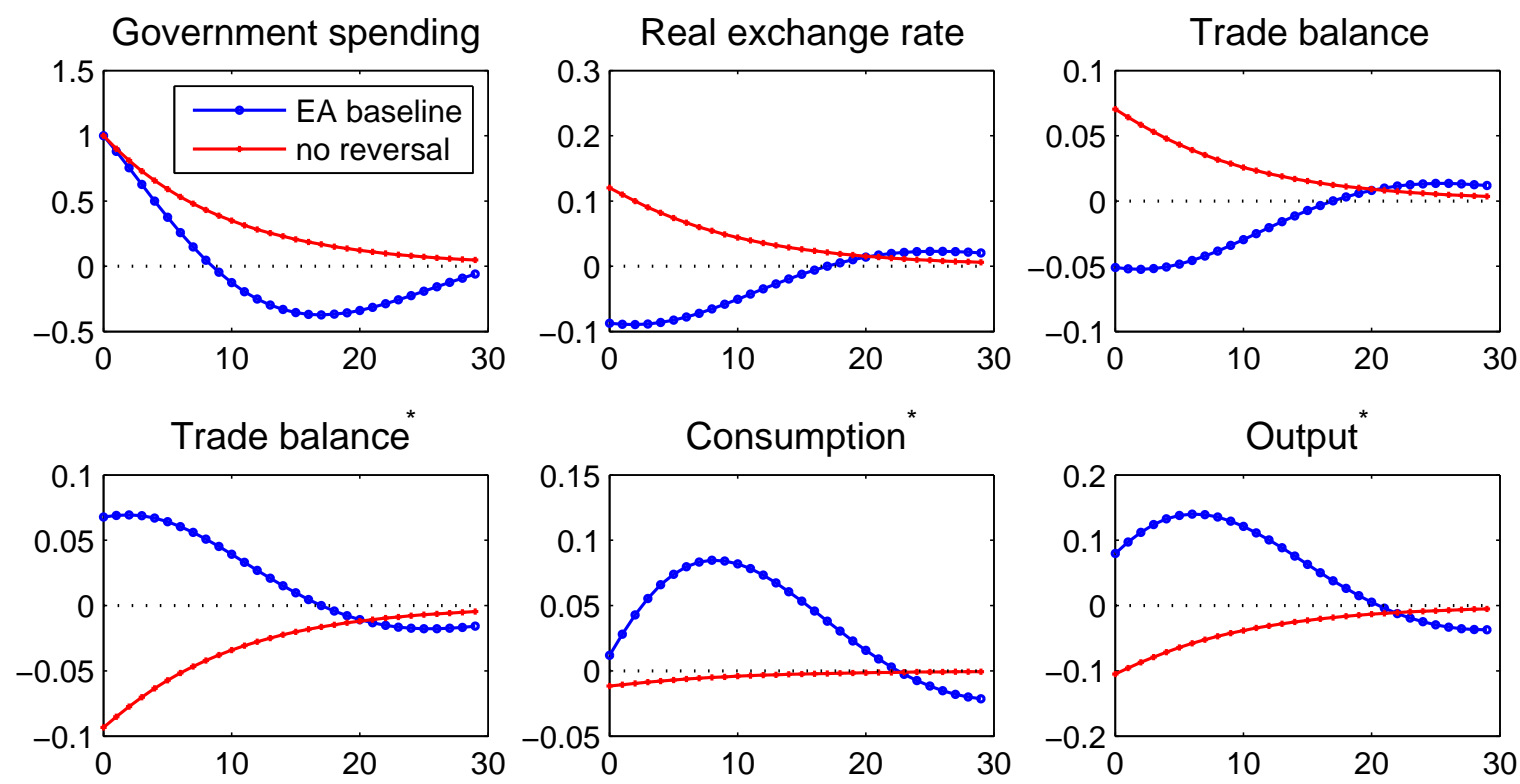

Figure 12: Effects of government spending shock in Home: baseline scenario for trade with EA (blue lines with circles) vs scenario without spending reversal (red lines with crosses). Notes: see figure 9.

It is important to emphasize that spending reversals exert a stimulating effect on global private expenditure only to the extent that their effect on inflation is partly accommodated by the central bank. What matters for fiscal transmission is that anticipated reversals induce expectations of lower real rates in the future (in turn reflecting partial accommodation of their deflationary effects over time, by virtue of the assumed Taylor rule). Via the expectations hypothesis, spending reversals then prevent Home long-term real rates from rising on impact in response to the Home fiscal expansion.

A related, important aspect of the transmission mechanism is whether monetary policy is constrained by the zero lower bond (ZLB) - a case which has gained renewed attention in the context of the global financial crisis 2007-09. Christiano et al. (2011) and Woodford (2011), among others, have shown that the government spending multiplier is likely to be considerably larger in an economic environment where monetary policy is unable to maintain its interest target due to a binding constraint on policy rates which prevents it from lowering rates. Under these conditions, monetary policy will accommodate a fiscal expansion. Similarly, using a two-country model Bodenstein et al. (2010) show that Home demand shocks (including to government spending) tend to have larger effects on Foreign domestic output, if the Foreign central bank is constrained in adjusting domestic policy rates by the ZLB.

Against this background, we also assess the extent to which a binding constraint on policy rates alters our results on the international spillovers of fiscal policy shocks. To do so, we posit that policy rates are fixed, either in the Home country, or in both countries (and only later determined by the interest 

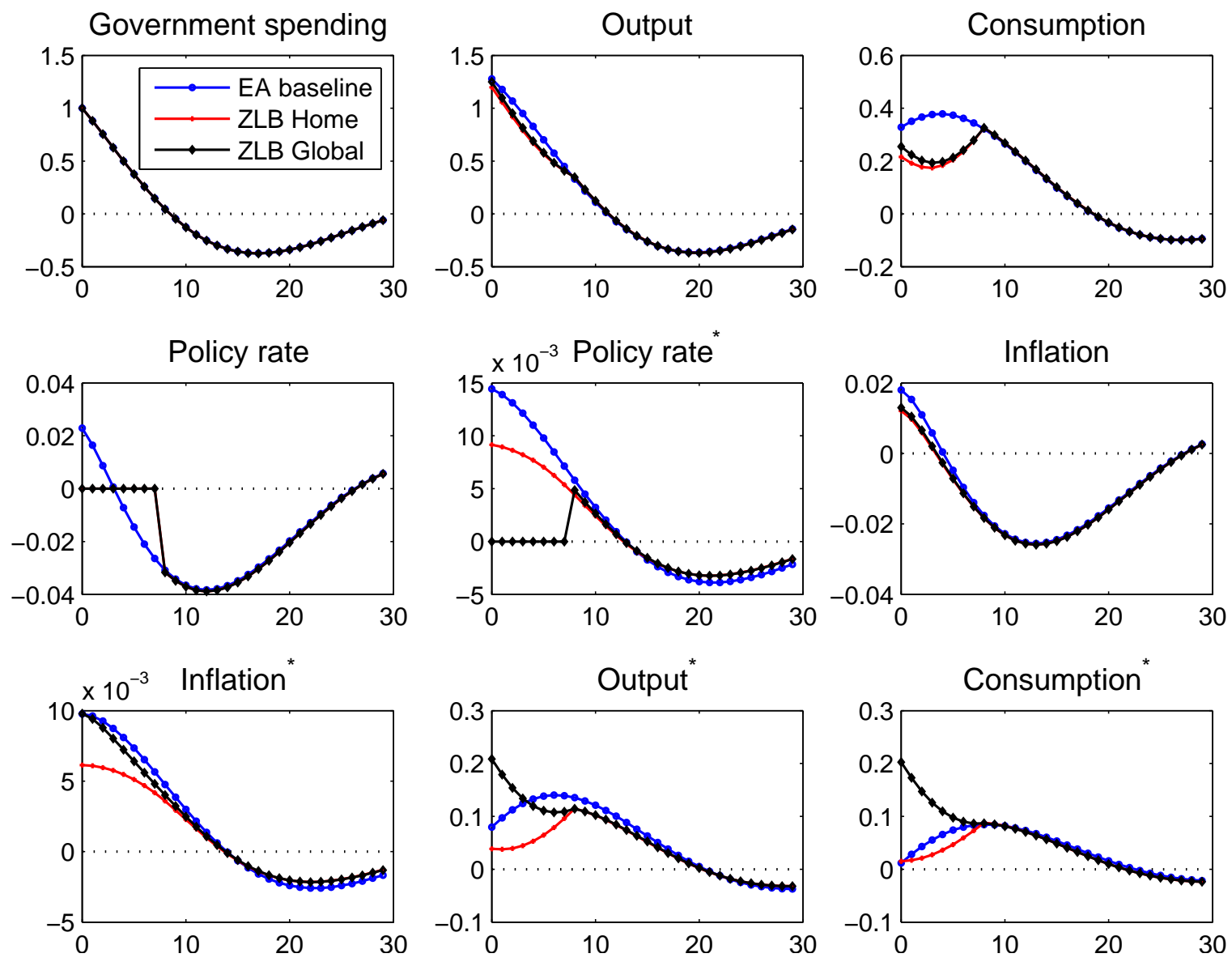

Figure 13: Effects of a government spending shock in the Home country: the baseline US-EA trade specification (blue lines with circles) is compared with specifications in which the policy rate is fixed for 8 quarters in the Home country (red line with crosses) or in both countries (black lines with diamonds). Notes: see figure 9. 
rate feedback rule). Figure 13 shows the results for two alternative specifications relative to our baseline case (blue lines with circles). In the first specification, we assume that Home policy rates are fixed for 8 quarters (red lines with crosses). In the second specification, rates are fixed for 8 quarters in both countries (black lines with diamonds).

For the first specification, relative to our baseline, we only observe a moderate increase in the effects of a fiscal expansion on domestic output, and only a small increase in international output spillovers. The effects of the constraint on the Home output response are limited here, because the reversal already induces a sizeable output effect on impact, as explained above. Importantly, with a reversal, Home policy rates fall relative to steady state before the constraint on the policy rate ceases to bind. We should stress that, if we did not posit spending reversals $\psi_{G}=0$, the Home output response would more than double.

In our specification with spending reversals, nonetheless, cross-border effects are sizeable when the constraint on policy rates affects both economies (see also Bodenstein et al. 2010). The cross-border effects are stronger here, because inflation dynamics would imply that the Foreign policy rate and hence the real interest rate rises during the first 8 quarters. With the constraint in place, instead, foreign real rates decline, stimulating Foreign private expenditure and hence Foreign output. International effects on Foreign output resulting from a Home fiscal expansion are thus considerably larger with a binding constraint on Foreign rates.

In conclusion, our analysis shows that standard theoretical models imply cross-border effects of national fiscal policy via a financial channel, with long-term rates driving the level of private demand. This channel encompasses the trade and interest rate channels emphasized in the traditional literature drawing on the Mundell-Fleming model. Importantly, however, these channels cannot be treated as independent of each other. Also, the analysis emaphsizes that what ultimately matters for the transmission of fiscal policy is the entire path of current and future mix of monetary and fiscal policy. Hence, the assessment of spillovers from short-run stimulus or retrenchment measures cannot be disjoint from the dynamics of budget adjustment and monetary reaction markets expect to prevail in response to them.

\section{Lessons for cooperation}

In the previous sections, we have provided time-series evidence suggesting large spillovers of fiscal policy measures on foreign economic activity, to an extent that standard business cycle models have a hard time to match. Yet, both the econometric evidence and our model analysis cast doubt on the importance of the "trade channel" by which fiscal stimulus in one country is meant to raise activity abroad via external demand. Instead, the transmission appears to operate via a "financial channel", that is, through the impact of fiscal policy on the long-term real interest rate and, eventually, on 
inter-temporal (consumption/saving) decisions. A key property of this channel is that anticipation of future policy measures, both monetary and real, are as consequential for the level of current private expenditures as current measures.

In this section, we further explore the working of a financial channel of transmission, and the case for cooperation, in an environment in which large fiscal imbalances raise issues regarding the ability of governments to sustain their budget policies.

To start with, we should re-iterate that evidence for non-negligible cross-border spillovers is an essential pre-requisite for international policy cooperation. Widespread beliefs that fiscal spillovers are large arguably motivated repeated calls for coordinated fiscal expansions in the initial phase of the crisis, with the objective to ensure a sufficiently high level of global demand vis-à-vis a failing economy. Our empirical evidence lends support to these beliefs.

It is worth emphasizing that, when calibrated to match the time-series evidence for the US, our theoretical model also backs the notion that the impact of current stimulus measures is magnified by expectations of systematic consolidation measures in the future. In our sample (ending in 2007), indeed, we detect a specific pattern of stimulus associated with anticipated spending reversals: government spending falls below trend a few quarters after a positive shock. An open issue is whether and to what extent the same pattern fits the most recent expansions in response to the global financial crisis. One may observe that, in the first phase of the crisis, emergency fiscal measures were rarely accompanied by a clear indication of the future budget correction required to ensure a stable fiscal outlook. Yet, it is hard to believe that private agents failed to anticipate the need for budget corrections via mix of spending cuts and tax increases at some point in the future, see Corsetti et al. (2010b) for further discussion.

Calls for cooperative stimulus have become less frequent, and more selective and asymmetric as the crisis evolved into a new stage, when, under the weight of the accumulated public liabilities, market and political pressures to correct the fiscal trajectory intensified. Especially in Europe, starting in 2010 , rising and volatile sovereign risk strengthened the case for immediate consolidation at a time when most economies were not on a sound recovery path, and financial markets remained fragile.

Late calls for cooperative stimulus measures have thus been directed towards surplus countries, pointing to the need for them to delay or reverse their consolidation plans, and use spare fiscal capacity to counteract the negative impact on global demand of early consolidation measures by deficit countries. Not surprisingly, these calls have been met with strong skepticism, backed by the following counter-argument: with sharply rising sovereign risk spreads in several countries, no government can consider its public finances beyond doubt; market turmoil justifies an exceptionally high degree of fiscal conservatism.

One may thus ask whether the end of the stimulus phase effectively marks the end of fiscal cooperation 
(at least in the policy discourse). In our view, a positive answer would be premature. But a discussion of fiscal coordination in the new phase of the policy response to the crisis is meaningful only to the extent that it incorporates sovereign risk, and especially its implications for the international transmission mechanism via the financial channel. This is a promising area of ongoing research, which (at the time of the writing) is still not fully developed. In what follows, we will provide some insights relying extensively on related work of ours carried out with André Meier and Keith Kuester.

\subsection{Sovereign risk and macroeconomic instability}

A key step towards understanding macroeconomic dynamics when fiscal authorities lack credibility and markets price sovereign default risk consists of recognizing that rising interest rate spreads on government borrowing spill over to the rest of the economy, that is, the borrowing conditions in the private sector deteriorate. There is substantive evidence that sovereign and private sector spreads move together, especially in countries that face fiscal strain. Not only such a pattern can be observed for financial institutions (which are directly or indirectly exposed to sovereign default via the composition of their portfolios) and for small (nonfinancial) firms that rely on local bank financing. It can also be documented for large international corporations with direct access to the bond markets, which in principle should be able to insulate their financing conditions from the country-specific problems. In Corsetti et al. (2011a) we show that these sovereign-risk spillovers constitute a distinct channel, that we dub the "sovereign-risk channel", through which fiscal policy may have profound consequences for macroeconomic stability.

To appreciate how the sovereign risk channel works, consider the possibility that private credit spreads rise with sovereign risk, because strained public finances imply a greater threat from taxation. In Corsetti et al. (2011a), we formalize this idea by building on the model suggested by Cúrdia and Woodford (2009), which allows us to consider the sovereign risk channel within a variant of the canonical New Keynesian model. Specifically, for given monetary policy, aggregate demand falls with an increase in sovereign risk as private borrowing costs increase.

As such, therefore, a sovereign risk channel tends to exacerbate the severity of recessions, especially when these are large. To the extent that a slowdown in economic activity translates into a marked deterioration of the budget deficits, rising borrowing costs for the public and the private sector will magnify the negative consequences of any given fundamental shock for aggregate demand and economic activity. On the upside, one could of course point out that under these circumstances budget corrections are likely to be less contractionary. In other words, the multiplier effects of spending cuts are smaller, if these are associated with a reduction of the sovereign risk spread and thus in the private borrowing costs.

However, according to our analysis, the overall response to fiscal policy measures is very sensitive to 
the strength of the spillover effect from public to private spreads and private expectations about the prospective length of the recession. It turns out that, with policy rates at the zero lower bound, small revisions in the anticipated duration of a recession, or small changes in the transmission of financial turmoil from the bond markets to banks and ultimately to borrowers, may fundamentally alter the government spending multiplier, possibly even turning its sign.

Moreover, sovereign risk can become a severe source of macroeconomic instability. Suppose that private expectations about the economy turn gloomier for some (non-fundamental) reason; firms and households expect demand to fall. Holding interest rates fixed, such expectations, in turn, imply an upward revision of the projected government deficit, as weaker economic activity leads to lower tax revenue and primary surpluses. Investors thus immediately ask for a higher risk premium on public debt. Via the sovereign-risk channel, however, the cost of private borrowing rises as well. The logic comes full circle as higher credit costs slow down activity, validating the initial adverse shift in expectations.

In tranquil times, this scenario of a self-fulfilling crisis can arguably be averted by the central bank. The central bank can in fact stem the link between public and private credit conditions through interest rate cuts or other measures, preventing pessimistic expectations from coming true. In crisis times, however, monetary policy may become increasingly constrained. If the central bank does not have sufficient room to manoeuvre, it cannot prevent expectations-driven downturns.

Regarding fiscal stabilization policies, we find that many of the standard prescriptions of fiscal policy no longer apply in the presence of severe sovereign risk. For instance, with policy rates at the zero lower bound and a deteriorated fiscal outlook, announcing counter-cyclical fiscal policy may be counterproductive, because anticipation of expansionary fiscal policy raises the risk of macroeconomic instability. Ex ante, desirable effects of stimulus measures are to be weighted against the possibility of macroeconomic instability - unless the government is able to match the stimulus by committing immediately and credibly to medium-term consolidation measures, stemming sovereign risk at its roots. On the other hand, announcing procyclical spending cuts motivated by keeping sovereign risk under control may not be sufficient to prevent instability. The problem is especially acute when the recession is expected to be long-lasting.

The analysis of the sovereign risk channel summarized above has so far being carried out in a closed economy context only. One may expect that a full-fledged open economy version of the same framework implies an even stronger role for financial factors driving of cross-border spillovers. For instance, in an open economy, equations (17) and (18) would be augmented by a term capturing the extent to which sovereign risk premia drive private borrowing costs. While this promising direction of research is still unexplored, it may nonetheless be useful to discuss some potential implications of a sovereign risk channel for international policy coordination. 


\subsection{Sovereign risk and international cooperation}

In the context of the ongoing global recession, volatile sovereign risk premia associated with imperfect credibility of fiscal policies have two relevant implications for international policy coordination. First, countries currently paying very low rates on their bonds are wary that further stimulus may have uncertain effects on the economy, as it may turn market sentiments around very quickly. The threat of rising spreads and hence macroeconomic instability justifies to some extent extremely conservative fiscal attitudes. But this in turn induces contractionary bias in the global economy. Second, all economies are increasingly likely to be exposed to sizable negative impulses, as market turmoil may at times force governments to resort to emergency consolidation measures or, more importantly, result in negative growth-debt spirals. Through international spillovers, the risks of a global meltdown in this context are extremely high.

There is large consensus on the need to restore policy credibility in deficit countries as a first step in achieving a sustained global recovery. At the same time, the scope for coordinated fiscal expansions by surplus countries is quite limited, because of the considerations above. In the most benign scenario, deficit countries can rely on moderate stimulus measures abroad, while implementing fiscal retrenchment and debt stabilization policies. Less limited, however, is the scope for coordinated measures preventing self-fulfilling crises. These are likely to include liquidity provision, coupled with some form of conditionality.

There are several reasons why cooperative agreements on this matter are particularly difficult to reach. For once, surplus countries may be extremely reluctant to engage on the ground that any help would do nothing but reduce the incentives for deficit countries to correct their imbalances. A widely held view in this respect holds that even financial assistance purely targeted to stem off a self-fulfilling run easily translates into a net transfer of resources to debtor countries. On the other hand, deficit countries emphasize that risk premia are strongly correlated across borders. This correlation blurs the relationship between painful domestic measures to stabilize debt and/or reform the economy and the market assessment of default risk. As result, it may discourage strong domestic initiatives in deficit countries.

Neither position has solid theoretical and empirical underpinnings. It stands to reason that, in a deep crisis, sheltering countries from self-fulfilling runs, while at the same time setting clear conditionality to prevent waste of international resources, would enhance, rather than reduce, the economic and political gains from budget and economic reforms in the deficit countries (see Corsetti et al. (2006), Morris and Shin (2006) and Corsetti and Dedola (2011)). By the same token, liquidity assistance is likely to work only if matched by thorough budget corrections and sensible domestic policies. Both groups can only gain from reducing the threat to world recovery from widespread market instability and expectations-driven downturn in the deficit countries. 


\section{Conclusion}

The case for fiscal coordination rests on evidence of significant cross border macroeconomic effects of fiscal measures. In this paper we have provided novel evidence on this matter, which is broadly in line with widespread priors among policymakers. Focusing on the US as a base country, our VAR estimates suggest that unexpected fiscal expansions have a large impact on economic activity in the UK and the euro area. These results are robust to alternative identification approaches.

Yet, against the equally widespread view that the transmission operates via a trade (external demand) channel, we find evidence that the transmission operates, instead, via a financial channel, which determines the expenditure/saving allocation. We have shown that a standard international business cycle model lends support to this interpretation.

We thus provide a new perspective on fiscal spillovers which is potentially consequential for policy coordination. A key role played by the financial channel implies that the impact of short-run fiscal measures on current expenditure crucially depends on expectations of fiscal and monetary adjustment over the medium- and long-run. Long-term bond prices reflect these expectations. It follows that the assessment and design of cooperative policies should not only focus on short-term measures but need to recognize the importance of providing forward guidance to markets. In fact, coordination on systematic (policy or budget) rules may be at least as important as coordination of specific measures in response to shocks.

In light of these results, in the last part of the paper we have sketched an analysis of international spillovers and challenges to policy coordination in a context of imperfect credibility. In this context, high sovereign risk premia put pressure on governments to implement strong budget consolidation measures. With markets pricing sovereign default, spillover effects on private borrowing costs profoundly alter the transmission mechanism. Not only do they undermine many of the basic prescriptions of stabilization policy derived from the standard model, they also expose the economy to the risk of downturns driven by self-fulfilling expectations. In this context, the case for international policy cooperation as a necessary step to reduce the risk of a sharp deepening of the ongoing recession becomes even stronger, but so becomes, unfortunately, the mistrust between surplus and deficit countries.

\section{References}

J. D. Amato and T. Laubach. Estimation and control of an optimization-based model with sticky prices and wages. Journal of Economic Dynamics and Control, 7:1181-1215, 2003.

R. Barro. Government spending is no free lunch. Wall Streat Journal (online January 22), 2009. 
R. Beetsma and M. Giuliodori. The effects of government purchases shocks: Review and estimates for the EU. The Economic Journal, 121:F4-F32, 2011.

R. Beetsma, M. Giuliodori, and F. Klaasen. Trade spill-overs of fiscal policy in the European Union: a panel analysis. Economic Policy, 48:640-687, 2006.

A. Benetrix and P. Lane. International differences in fiscal policy during the global crisis. IIIS Discussion Paper No. 336, 2010.

O. J. Blanchard and R. Perotti. An empirical characterization of the dynamic effects of changes in government spending and taxes on output. Quarterly Journal of Economics, 117(4):1329-1368, November 2002.

M. Bodenstein, C. J. Erceg, and L. Guerrieri. The effects of foreign shocks when interest rates are at zero, 2010. CEPR Discussion paper 8006.

H. Bohn. The behavior of U.S. public debt and deficits. Quarterly Journal of Economics, 113: 949-963, 1998.

M. B. Canzoneri, R. E. Cumby, and B. Diba. New view on the transatlantic transmission of fiscal policy and macroeconomic policy coordination. In M. Buti, editor, Monetary and Fiscal Policies in EMU, pages 283-311. Cambridge University Press, 2003.

L. Christiano, M. Eichenbaum, and S. Rebelo. When is the government spending multiplier large? Journal of Political Economy, 119(1):78-121, 2011.

J. F. Cogan, T. Cwik, J. B. Taylor, and V. Wieland. New Keynesian versus old Keynesian government spending multipliers. Journal of Economic Dynamics and Control, 34, 2010.

G. Corsetti and L. Dedola. Fiscal crises, confidence and default: A bare-bones model with lessons for the euro area. Cambridge University, mimeo, 2011.

G. Corsetti and G. J. Müller. Twin deficits: Squaring theory, evidence and common sense. Economic Policy, 48:598-638, 2006.

G. Corsetti, B. Guimaraes, and N. Roubini. International lending of last resort and moral hazard: A model of imf's catalytic finance. Journal of Monetary Economics, 53(3):441-471, 2006.

G. Corsetti, L. Dedola, and S. Leduc. International risk-sharing and the transmission of productivity shocks. Review of Economic Studies, 75(2):443-473, 2008.

G. Corsetti, L. Dedola, and S. Leduc. Optimal monetary policy in open economies. In B. M. Friedman and M. Woodford, editors, Handbook of Monetary Economics. Elsevier, 2010a. 
G. Corsetti, K. Kuester, A. Meier, and G. J. Müller. Debt consolidation and fiscal stabilization of deep recessions. American Economic Review, Papers and Proceedings, 10:41-45, $2010 \mathrm{~b}$.

G. Corsetti, A. Meier, and G. J. Müller. Cross-border spillovers from fiscal stimulus. International Journal of Central Banking, 6:5-37, 2010c.

G. Corsetti, K. Kuester, A. Meier, and G. J. Müller. Sovereign risk and the effects of fiscal retrenchment in deep recessions. Federal Reserve Bank of Philadelphia Working paper 11-43, 2011a.

G. Corsetti, A. Meier, and G. J. Müller. What determines government spending multipliers? mimeo, $2011 b$.

G. Corsetti, A. Meier, and G. J. Müller. Fiscal stimulus with spending reversals. Review of Economics and Statistics, forthcoming, 2011c.

V. Cúrdia and M. Woodford. Credit frictions and optimal monetary policy. mimeo, 2009.

T. Cwik and V. Wieland. Keynesian government spending multipliers and spillovers in the euro area. Economic Policy, forthcoming, 2010.

B. De Paoli. Monetary policy and welfare in a small open economy. Journal of International Economics, 77:11-22, 2009.

M. Del Negro, G. Eggertsson, A. Ferrero, and N. Kiyotaki. The great escape? a quantitative evaluation of the feds non-standard policies. mimeo, 2010.

D. Domeij and M. Flodén. The labor-supply elasticity and borrowing constraints: Why estimates are biased. Review of Economic Dynamics, 9(2):242-262, 2006.

C. J. Erceg, D. Henderson, and A. Levin. Optimal monetary policy with staggered wage and price contracts. Journal of Monetary Economics, 46:281-313, 2000.

J. Galí and R. Perotti. Fiscal policy and monetary integration in Europe. Economic Policy, 37: 534-572, 2003.

N. Girouard and C. André. Measuring Cyclically-Adjusted Budget Balances for OECD Countries. OECD Economics Department Working Paper No. 434, 2005.

M. Horton, M. Kumar, and P. Mauro. The state of public finances: A cross-country fiscal monitor, 2009. IMF Staff Position Note 08/01.

International Monetary Fund. Fiscal exit: From strategy to implementation. Fiscal Monitor, November, 2010. 
International Monetary Fund. Shifting gears: Tackling challenges on the road to fiscal adjustment. Fiscal Monitor, April, 2011.

S. Kim and N. Roubini. Twin deficit or twin divergence? Fiscal policy, current account, and real exchange rate in the U.S. Journal of International Economics, 74(2):362-383, 2008.

E. M. Leeper. Equilibria under 'active' and 'passive' monetary and fiscal policies. Journal of Monetary Economics, 27(1):129-147, February 1991.

A. Meier. Panacea, curse, or nonevent? unconventional monetary policy in the united kingdom. IMF Working paper 09/163, 2009.

T. Monacelli and R. Perotti. Fiscal policy, the trade balance and the real exchange rate: Implications for international risk sharing. mimeo, 2006.

S. Morris and H. S. Shin. Catalytic finance: When does it work? Journal of International Economics, 70(1):161-177, 2006.

E. Nakamura and J. Steinsson. Five facts about prices: A reevaluation of menu cost models. Quarterly Journal of Economics, 123:1415-1464, 2008.

V. A. Ramey. Identifying government spending shocks: It's all in the timing. Quarterly Journal of Economics, 126(1):1-50, 2011.

C. Reinhart and K. Rogoff. This time is different: A panoramic view of eight centuries of financial crisis, 2008. NBER Working Paper 13882.

J. J. Rotemberg and M. Woodford. An optimization-based econometric framework for the evaluation of monetary policy. NBER Macroeconomics Annual, 12:297-346, 1997.

A. Sutherland. Incomplete pass-through and the welfare effects of exchange rate variability. Journal of International Economics, 65(2):375-399, 2005.

H. Uhlig. Some fiscal calculus. American Economic Review, 100:30-34, 2010.

M. Woodford. Interest \& Prices. Princeton University Press, Princeton, New Jersey, 2003.

M. Woodford. Simple analytics of the government expenditure multiplier. American Economic Journal: Macroeconomics, 3:1-35, 2011. 